\title{
MODALIDAD DE COBERTURA POR RECLAMACIÓN O “CLAIMS MADE” EN COLOMBIA"
}

\section{CLAIMS MADE COVERAGE IN COLOMBIA}

\author{
MARÍA DEL PILAR BEGUÉ HOYOS** \\ DANIELA VALENCIA CARDONA***
}

Fecha de recepción: 15 de abril de 2021 Fecha de aceptación:30 de mayo de 2021 Disponible en línea: 30 de junio de 2021

Para citar este artículo/To cite this article

\begin{abstract}
Begué Hoyos, María del Pilar \& Valencia Cardona, Daniela, Modalidad de cobertura por reclamación o "Claims made" en Colombia, 54 Rev.Ibero-Latinoam.Seguros, 305-360 (2021).

https://doi.org/10.11144/Javeriana.ris54.mcrc

doi:10.11144/Javeriana.ris54.mcrc
\end{abstract}

\footnotetext{
* Tomado del trabajo presentado para optar por el título de Especialistas en derecho de seguros de la Facultad de Ciencias Jurídicas de la Pontificia Universidad Javeriana. Agradecemos a nuestra asesora, Patricia Jaramillo Salgado, por su compañía, apoyo y sugerencias durante este proceso de investigación y en la construcción de este artículo.

** Abogada de la Universidad EAFIT, especialista en derecho de seguros de la Pontificia Universidad Javeriana. Analista de Soluciones Patrimoniales en Seguros Generales Suramericana S.A. pilibeho@ hotmail.com Orcid: https//orcid.org/0000-0002-4536-1438

*** Abogada de la Universidad EAFIT, especialista en responsabilidad civil y seguros de la misma Universidad, especialista en derecho de seguros de la Pontificia Universidad Javeriana. Directora de Soluciones Patrimoniales en Seguros Generales Suramericana S.A. danivalen88@gmail.com Orcid: https:// orcid.org/0000-0001-6836-5426
} 


\section{RESUMEN}

En Colombia han surgido una serie de polémicas que tienen relación con la aplicación y la legalidad de la modalidad de cobertura Claims made. Esto se ha evidenciado especialmente en el campo de la responsabilidad fiscal con los recientes fallos de la Contraloría General de la República en los que ha inaplicado las normas de seguros, particularmente en lo referido a esta modalidad de cobertura. Lo anterior se ejemplificará con algunos casos como el del Instituto de Desarrollo Urbano y el reciente proceso de Reficar.

Pese a que la Corte Suprema de Justicia ha reconocido y aplicado esta modalidad, conforme a lo dispuesto en la ley, los salvamentos de voto de los magistrados Ariel Salazar y Armando Tolosa han generado un impacto negativo en la concepción de los seguros que la incluyen al usar como argumentos en su contra que se trata de una práctica ilegal y abusiva.

Teniendo en cuenta lo anterior este artículo muestra en qué consiste esta modalidad, cuál es su origen, cómo es percibida y desarrollada por distintos doctrinantes y la forma en que ha sido aplicada en la jurisprudencia de las Altas Cortes. Además, se expondrán las manifestaciones realizadas por la Superintendencia Financiera y, finalmente, algunas propuestas para solucionar las controversias que genera, bajo el entendido de que la modalidad de cobertura Claims made es completamente legal y que debe aplicarse técnicamente en las controversias de seguros que surjan.

Palabras claves: Claims made, reclamación, seguros, responsabilidad fiscal, Ley 389 de 1997. 


\begin{abstract}
In the last few years the application and legality of the Claims Made coverage has been discused in Colombia, creating controversy in the insurance and reinsurance market. These has been evident and critical in the fiscal liability field, with the recent decisions of the Contraloria General de la República in several cases, such as the ones concerning the Instituto de Desarrollo Urbano and Reficar -which will be explained later-, where insurance regulations regarding this type of coverage not only was not applied but the arguments for doing so were wrongly founded.
\end{abstract}

Despite the fact that the Corte Suprema de Justicia has recognized and applied this coverage modality, in accordance with the provisions of the law, the magistrates Ariel Salazar and Armando Tolosa dissented their votes in two ocassions arguing that the Claims made coverage was an illegal and abusive practice, which created a negative impact on the understanding of the insurances with this type of coverage

Taking in consideration the above, this article will show what is the Claims made coverage, its origin, how it has been perceived and developed by experts in the field and the way in which it has been applied and interpreted within the jurisprudence of the Colombian High Courts. In addition, the statements made by the Superintendencia Financiera will be exposed and, finally, some recommendatios to aid solve the controversies that the Claims made modality generates, understanding that it is legal and that it must be applied technically in the insurance litigations that arise in Colombia.

Key words: Claims made, Claims, insurance, fiscal liability, Law 389 of 1997.

SUMARIO: Introducción. 1. Origen de la modalidad de cobertura por reclamación o Claims made. 2. La modalidad de cobertura por reclamación o Claims made. 2.1 Reclamación o Claims made. 2.2. Modalidad Sunset. 3. Postura de la Corte Suprema de Justicia. 3.1. Los salvamentos de voto. 4. Postura del Consejo de Estado. 5. Postura de la Superintendencia Financiera de Colombia. Aplicaciones de la modalidad de cobertura por reclamación o Claims made por la Contraloría General de la República. 7. Propuestas. 8. Conclusiones. 9. Bibliografía. 


\section{INTRODUCCIÓN}

La Ley 389 de 1997, en su artículo 4º, consagró la modalidad de cobertura Claims made o reclamación, para los seguros de responsabilidad civil buscando, en primer lugar, actualizar la ley de seguros a las tendencias internacionales del mercado asegurador y reasegurador, y para resolver, además, las problemáticas que presentaba la modalidad de cobertura ocurrencia, frente a las reclamaciones denominadas de "cola larga".

En los primeros años de vigencia de esta norma no hubo mayores controversias al respecto; sin embargo, como lo afirma el tratadista Carlos Ignacio JARAMILlo (2011, pp. 153-154), esta es una temática que en los últimos años ha suscitado gran interés que de ninguna forma es pacífico o generalizado. Indica que, "muy por el contrario, se ha traducido en escenario de aceradas polémicas, no siempre simétricas, en razón de que hay diversidad de grados y matices: unos abogan por su aceptación plena e incondicional; otros la admiten, pero con reparos y limitaciones; un grupo de autores, con inequívocas reservas, efectúan una severa e implacable crítica, y otros, aún más radicales, se inclinan por su descalificación íntegra en el plano legal o convencional e, incluso, en sede constitucional, como ciertos doctrinantes no dudan en aseverar".

En Colombia esta situación se ha evidenciado especialmente en el campo de la responsabilidad fiscal. En la última década la Contraloría General de la República ha producido fallos en los que, si bien ha pretendido la protección del patrimonio de entidades de orden nacional por cuantías muy elevadas, ha inaplicado o pasado por alto las definiciones normativas respecto a la ley de seguros, particularmente en lo referido a las cláusulas de modalidad temporal de cobertura por reclamación o Claims made, al momento de vincular y condenar a los terceros civilmente responsables en diversos casos que más adelante se analizarán.

Ello ha tenido un gran impacto en el sector asegurador y reasegurador, puesto que ha generado para los actores de este mercado una gran incertidumbre, especialmente para los reaseguradores nacionales e internacionales, quienes han reducido sus capacidades o han decidido no suscribir más negocios en modalidad Claims made, haciendo difícil para las aseguradoras colombianas continuar con esta oferta.

Ahora bien, aunque la Corte Suprema de Justicia ha reconocido y aplica esta modalidad conforme a lo dispuesto en la ley, dos salvamentos de voto de los magistrados Ariel Salazar y Armando Tolosa en sentencias recientes (2017 y 2018), generaron un impacto negativo en la concepción de los seguros con esta modalidad de cobertura, pues los argumentos utilizados fueron, entre otros, que se trataba de una práctica ilegal y abusiva (a ellos nos referiremos más adelante).

Por lo anterior, analizaremos en qué consiste la modalidad Claims made para determinar si esta es legal y cuál sería su aplicación técnica en una controversia, teniendo en cuenta la posición de la Corte Suprema de Justicia, el Consejo de Estado y la Superintendencia Financiera de Colombia. 


\section{ORIGEN DE LA MODALIDAD DE COBERTURA POR RECLAMACIÓN O CLAIMS MADE}

La modalidad de cobertura por reclamación o "Claims made" se originó a mediados de los años 80, como una solución del mercado asegurador y reasegurador a los problemas temporales, económicos y jurídicos que surgieron por la existencia de los riesgos de cola larga, de extensos términos de prescripción existentes y de la manifestación tardía de varias enfermedades de la época como la asbestosis, talidomida, DES (diethylistibesterol) y el Agente Naranja, que hacían muy costosa la reclamación ante el seguro ${ }^{1}$. Esto tuvo efectos importantes para los aseguradores sobre todo en los seguros de responsabilidad civil, que para la época solo operaban bajo la modalidad de cobertura por ocurrencia.

Esta modalidad en este tipo de seguros considera que el siniestro es el hecho dañoso realizado por el asegurado durante la vigencia del contrato de seguro que genera un perjuicio a un tercero ${ }^{2}$. Sin embargo no todo es sencillo ni perfecto bajo ella ${ }^{3}$, pues se le han identificado, al menos, dos falencias fundamentales: en primer lugar, a pesar de materializarse el riesgo asegurado, no habrá una verdadera obligación de indemnizar a quien sufre los perjuicios si este no presenta la debida reclamación ya sea directamente al asegurado o a la compañía aseguradora vía acción directa; y, en segundo lugar, el daño no siempre se manifiesta en el momento exacto de la realización de la conducta o la ocurrencia de los hechos, situación que se ve en los llamados daños diferidos o tardíos ${ }^{4}$.

Esto generó consecuencias importantes para las compañías aseguradoras y reaseguradoras de la época, pues la modalidad las obligaba a mantener reservas constituidas durante muchos años para poder hacer frente a las futuras reclamaciones por hechos que hubieren ocurrido tiempo atrás en vigencia de las pólizas ${ }^{5}$. En muchos

\footnotetext{
1 Uribe Lozada, Nicolás (2013). El régimen general de responsabilidad de los administradores de sociedades y su aseguramiento. Pontificia Universidad Javeriana, Facultad de Ciencias Jurídicas. Grupo Editorial Ibáñez.

2 Parte de la doctrina (Fernández Muñoz, 2002, p. 339) y (Uribe Lozada, 2013) consideran que el siniestro en los seguros de responsabilidad civil siempre ha sido considerado un hecho complejo y difícil de ubicar temporalmente en un preciso instante. Esto ha llevado a la formulación de diversas teorías que pretenden explicar cuándo se entiende producido el siniestro que da origen a la indemnización a cargo de la compañía aseguradora. Así, Andrés OrdóñEZ (El contrato de seguro. La Ley 389 de 1997 y otros estudios, 1998, pp. 87-94) y Juan Manuel DíAz-Granados (El seguro de responsabilidad civil, 2012, pp. 149-150) destacan la teoría del hecho dañoso y la teoría del reclamo de la víctima. Este último indica que "el primero, aquel relativo a la ocurrencia del siniestro que estará marcado por el acaecimiento del hecho externo imputable al asegurado, que por cierto será el elemento o requisito constitutivo o de existencia de cobertura, el segundo momento, será aquel de la reclamación que marcará un requisito de mera exigibilidad”.

3 Así lo sostiene Nicolás URIBE (2013, p. 343) indicando que la modalidad de cobertura por ocurrencia no está libre de polémicas.

4 Joaquín GARrigues (Contrato de seguro terrestre, 1983, p. 375) manifestaba que el siniestro en el seguro de responsabilidad civil no se produce en un solo hecho, sino en una sucesión de hechos, que comienza en el hecho culposo causante del daño. Y aclaraba que "La ley del seguro ha considerado siniestro precisamente ese hecho inicial, aunque hay que reconocer que el verdadero siniestro no se produce hasta tanto se reclame la correspondiente reparación por la víctima del daño".

5 Este problema fue reconocido igualmente por la doctrina (ORDóÑEZ, Andrés. 1998. El contrato de seguro. La Ley 389 de 1997 y otros estudios. Universidad Externado de Colombia, pp. 98-99): “durante
} 
casos, las aseguradoras debían mantener en suspenso sus obligaciones, lo cual suponía una gran preocupación, motivo por el cual se hizo necesario crear una nueva modalidad de cobertura.

Para Mónica Fernández (2002, p. 220) la creación de la modalidad Claims made se debió a los largos períodos de prescripción y la incertidumbre que estos causaban a las aseguradoras, que no querían tener latente el riesgo de una reclamación mientras transcurría este tiempo, por lo que se creó una estrategia por parte de los mercados reaseguradores, consistente en hacerle saber a las compañías aseguradoras que no estarían dispuestos a mantener las reservas técnicas en tales casos, anuncio que conllevó a que el otorgamiento del reaseguro estuviera condicionado a la inclusión de cláusulas de limitación temporal en el seguro de responsabilidad civil.

Es de resaltar, que autores como Eduardo PAVELEK ZAMORA, referenciado por URIBE LOZADA (2013, p. 461) consideran que esta modalidad no se creó solamente en favor del asegurador, pues indica que este es un sistema que hace posible estipular coberturas retroactivas o ampliar el plazo de las reclamaciones aunque la póliza se hubiere extinguido, lo que definitivamente genera mayores beneficios para los asegurados y su posibilidad de cubrir o asegurar riesgos distintos, novedosos.

Pues bien, luego de más de 10 años, en 1997, “esta modalidad que se expandía con fuerza en la práctica contractual de numerosos países", fue adoptada en el ordenamiento jurídico colombiano a partir de la expedición de la Ley 389. El sector asegurador aprovechó esa oportunidad legislativa y siguiendo la experiencia española y, en general, la tendencia mundial, logró que en el artículo cuarto de la Ley 389 se permitiera oficialmente el uso en Colombia de seguros con base de cobertura por reclamación pues hasta el momento, la única modalidad permitida en Colombia, era la tradicional modalidad de ocurrencia.

En la exposición de motivos de la ley mencionada, se puso de manifiesto que la modernización de la institución del seguro era necesaria e inminente y es por ello que dentro de los propósitos de la norma estaban también lograr la consensualidad del contrato de seguro, permitir la prueba de éste a través de escrito o confesión, hacer obligatoria la entrega de la póliza en los 15 días siguientes a su suscripción y, finalmente, permitir la entrada de dos modalidades de cobertura temporales nuevas: la de descubrimiento y la de reclamación.

\footnotetext{
mucho tiempo en la incertidumbre sobre las sumas de dinero que tendrá que erogar eventualmente como consecuencia de la calidad de asegurador, lo cual implica: a) dificultad en la evaluación y control de las reservas técnicas de las aseguradoras; b) prolongación indefinida de la constitución de esas reservas y c) mantenimiento de contratos en estado de suspensión, cuestión que a su vez puede depender de circunstancias de hecho, en el caso de los daños que se evidencian con mucha posterioridad a las conductas imputables al asegurado, y de derecho, cuando los plazos de prescripción de las acciones de las víctimas contra los asegurados son demasiado largos".

6 Jaramillo, Carlos Ignacio (2011). Delimitación temporal de la cobertura en el Seguro de la Responsabilidad Civil - Adopción del sistema de aseguramiento comúnmente conocido como "Claims made”. Revista Ibero-latinoamericana de Seguros, p. 151.
} 
Con esto último se pretendía que Colombia se acogiera a las tendencias del mercado mundial en seguros de manejo y responsabilidad, que las compañías aseguradoras pudieran cubrir hechos ocurridos con anterioridad al contrato de seguro $-\mathrm{y}$ que se descubrieran o reclamaran durante la vigencia del seguro-, que en temas de responsabilidad se pudieran cubrir las reclamaciones por hechos tardíos $\mathrm{y}$, también, que el país pudiera contar con apoyo internacional en reaseguro para otorgar coberturas más interesantes para los asegurados, como en los seguros ambientales, de productos defectuosos y de responsabilidades profesionales ${ }^{7}$.

Fue así, pues, como el 18 de julio de 1997 se promulga la Ley 389, cuyo artículo $4^{\circ}$ estableció la novedad de poderse pactar por las partes del contrato dos nuevas modalidades de cobertura. El artículo indica lo siguiente:

ARTICULO 4o. En el seguro de manejo y riesgos financieros y en el de responsabilidad la cobertura podrá circunscribirse al descubrimiento de pérdidas durante la vigencia, en el primero, y a las reclamaciones formuladas por el damnificado al asegurado o a la compañia durante la vigencia, en el segundo, asi se trate de hechos ocurridos con anterioridad a su iniciación.

Así mismo, se podrá definir como cubiertos los hechos que acaezcan durante la vigencia del seguro de responsabilidad siempre que la reclamación del damnificado al asegurado o al asegurador se efectúe dentro del término estipulado en el contrato, el cual no será inferior a dos años.

PARÁGRAFO. El Gobierno Nacional, por razones de interés general, podrá extender lo dispuesto en el presente artículo a otros ramos de seguros que asi lo ameriten.

Como se estableció en el laudo arbitral del 2020 en el caso del Fondo Nacional del Ahorro Carlos Lleras Restrepo en contra de Mapfre Seguros Generales De Colombia S.A, la ley 389 vino a introducir la posibilidad de amparar hechos claramente pretéritos, pero descubiertos o reclamados durante la vigencia, con lo cual se morigeró la categórica imposibilidad de asegurar el riesgo putativo consagrada en el artículo 1054 del ordenamiento mercantil.

Para los seguros de responsabilidad civil, a partir de ese momento se permitió que en Colombia coexistieran dos sistemas de aseguramiento: el tradicional de

\footnotetext{
7 El doctrinante Bernardo Botero (Ponencia La teoría y la práctica del seguro por reclamación o seguro Claims made, 2012) citado en El régimen general de responsabilidad de los administradores de sociedades y su aseguramiento (Uribe Lozada, 2013) explicó las razones que motivaron la expedición de esta Ley: "sin dejar de reconocer, por supuesto la influencia de la legislación española, la verdad es que fue más la presión generada por los mercados internacionales de reaseguro que se negaban otorgar cobertura de responsabilidad civil para algunas actividades bajo el tradicional enfoque de "ocurrencia" [...]. Habida consideración de las manifiestas dificultades para la obtención de reaseguro o del elevado costo del mismo bajo la modalidad de ocurrencia, las aseguradoras colombianas, a través de su entidad gremial FASECOLDA, aprovechando el trámite en curso ante el Congreso de la República del proyecto de ley mediante el cual se proponía la modificación de los artículo 1036 y 1046 del Código de Comercio [...] recomendaron la introducción de un artículo -en definitiva el artículo $4^{\circ}$ de la Ley 389 de 1997mediante el cual en su inciso primero se consagrase la viabilidad legal de los seguros Claims made".
} 
ocurrencia y el extraordinario, fundamentado en la reclamación; obviamente alternativos y no simultáneos ${ }^{8}$.

Esto significó que en tales seguros se admitiera la posibilidad de pactar las denominadas cláusulas Claims made y que por medio de ellas la cobertura del seguro quedara vinculada a la reclamación que realizare la víctima, independientemente de que el hecho dañoso hubiere ocurrido dentro de la vigencia del contrato o antes de su formalización ${ }^{9}$. Es decir, en donde pudiera entenderse el siniestro ya no como la ocurrencia del hecho dañoso, como se comprendía tradicionalmente, sino como la reclamación presentada por la víctima al Asegurado o Asegurador.

Esto ha generado discusiones y posiciones contrarias; a pesar de ello, la Ley que la consagra continúa vigente, se utiliza en la práctica aseguradora y hasta el momento esta modalidad de cobertura temporal no ha sido declarada inconstitucional por la Corte Constitucional colombiana. Así lo estableció el tribunal de arbitramento iniciado por el Fondo Nacional del Ahorro en contra de Mapfre, como puede verse en el aparte del fallo que a continuación se cita:

(...) la facultad otorgada por el artículo $4^{\circ}$ de esta Ley es de carácter taxativo y excluyente, de modo que únicamente podrá pactarse la modalidad "por descubrimiento" en contratos de seguro que amparen el manejo de recursos y en general las consecuencias de infidelidad y riesgos financieros y, a su turno, la modalidad "por reclamación" o "Claims made" en los seguros que cubren la responsabilidad civil, conclusión que no requiere de mayores elucubraciones, ni de interpretación alguna, puesto que así quedo claramente referido en el artículo mencionado. (Subrayado propio)

No obstante, FERNÁNDEZ (2002, p. 241) consideró que este artículo podía ser un atentado contra los derechos del consumidor y, en consecuencia, contrario a los preceptos constitucionales. Por lo tanto, de acuerdo con su visión del tema, la adopción de las cláusulas Claims made podía traer múltiples problemas y eventual violación de normas constitucionales, por lo que se podría analizar la procedencia del ejercicio del control constitucional, mediante la denominada excepción de inconstitucionalidad, como mecanismo posible de solución.

Solo hasta el 2008 en la sentencia C-388, la Corte Constitucional realizó un acercamiento sobre el tema (y hasta ahora ha sido el único), pero se declaró inhibida para proferir un fallo sobre la constitucionalidad del artículo $4^{\circ}$ de la Ley 389. Lo anterior ya que el ciudadano que interpuso la acción de inconstitucionalidad en contra de esta norma, a pesar de invocar la violación al derecho de igualdad entre el asegurado y el beneficiario de un seguro para fundamentar su demanda, no argumentó cómo, en su concepto, se violaba el artículo 13 de la Constitución y se limitó a expresar, que, en su opinión, pactar la modalidad de reclamación o Claims made constituía una situación inconveniente para el asegurado.

\footnotetext{
${ }^{8}$ Jaramillo, Carlos Ignacio. (2011). Delimitación temporal de la cobertura en el Seguro de la Responsabilidad Civil - Adopción del sistema de aseguramiento comúnmente conocido como "Claims made" -. Revista Ibero-latinoamericana de Seguros, p. 152.

${ }^{9}$ Así fue concebido por Mónica Lucía Fernández MuÑoz. (2002). Las cláusulas Claims made en el contrato de seguro de responsabilidad civil. Revista Estudios Sociojurídicos, p. 17.
} 
Por ende, en tal fallo la Corte se pronuncia sobre la exequibilidad del artículo 1131 del Código de Comercio, sobre lo cual no se ahondará, y, como se mencionó, se declara inhibida para fallar sobre la constitucionalidad del artículo $4^{\circ}$ de la Ley 389 de $1997^{10}$.

\section{LA MODALIDAD DE COBERTURA POR RECLAMACIÓN O CLAIMS MADE}

En adición de la consagración incluida en el artículo $4^{\circ}$ de la Ley 389 , la doctrina (e incluso la Corte Suprema de Justicia, como se verá más adelante) ha establecido diversas alternativas para el uso de la cláusula Claims made:

- "Aquellas cuya cobertura está condicionada a que el hecho dañoso y la reclamación de la víctima se produzcan dentro de la vigencia del contrato.

- Aquellas cuya cobertura está condicionada a que el hecho dañoso se produzca dentro de la vigencia del contrato y la reclamación de la víctima dentro de la vigencia del contrato o en el término estipulado en éste, el cual no será inferior a dos años.

- Aquellas cuya cobertura está condicionada a que la reclamación se realice durante la vigencia del contrato, así se trate de hechos ocurridos con anterioridad a su iniciación"11.

Frente a esto, es cierto que la norma no solo incorporó las modalidades de descubrimiento y reclamación o Claims made, sino que, además, admitió la existencia de una modalidad adicional denominada "Sunset", y que para estas alternativas surgen algunos elementos que podrán categorizarse como características fundamentales de la modalidad.

A continuación, pues, se procederá a desarrollar con especial énfasis cómo opera la modalidad Claims made, qué efectos tiene, cuáles son sus rasgos característicos y las variaciones y alternativas que puede presentar e, incluso, se expondrán las opiniones de diferentes doctrinantes sobre su legalidad, aplicabilidad y validez. Sin embargo, es importante resaltar que se le dedicarán, también, algunas líneas a la modalidad Sunset mencionada.

\footnotetext{
${ }_{10}$ Frente al tema la Superintendencia Financiera de Colombia se pronunció indicando que: "el legislador introdujo en nuestro ordenamiento a través de la Ley 389 de 1997 la posibilidad de que las partes en el contrato de seguro de responsabilidad civil introduzcan estipulaciones que limiten en el tiempo la cobertura de una manera concreta -las denominadas cláusulas "Claims made"- con el fin de optimizar la regulación del mercado asegurador, permitir su sostenibilidad, así como la reducción del costo de las primas en función de la reducción del tiempo de las reservas técnicas, tal como se señaló en su momento en la correspondiente exposición de motivos".

Y finalmente, sobre el entendimiento de esta modalidad de cobertura por reclamación o Claims made, confirma, como ya lo había hecho en 2002, que se trata de una "situación de ejercicio de la autonomía de la voluntad de las partes" y que esta únicamente se limita "al señalamiento del término mínimo previsto para la presentación de la reclamación de la víctima al asegurado o a la compañía", que ya se dijo, es de dos años, y por lo que resulta "legalmente admisible establecer un término mayor para la presentación de la reclamación".

11 Fernández Muñoz, Mónica Lucía. (2002). Las cláusulas Claims made en el contrato de seguro de responsabilidad civil. Revista Estudios Sociojurídicos, p. 223.
} 


\subsection{Reclamación o Claims made}

Para comenzar es importante hacer hincapié en el significado o concepción que se tiene de la modalidad. URIBE LozADA (2013, p. 346) indica que esta modalidad es diametralmente diferente en su concepción al tradicional mecanismo basado en la ocurrencia pura, ya que admite el amparo de hechos pasados pues el detonante de la cobertura es un hecho posterior a la producción del daño, consistente en la solicitud de indemnización que haga la víctima al asegurado o a la aseguradora.

Por su parte, Carlos Ignacio Jaramillo (2011, pp. 321-322) indica que esta modalidad no es una delimitación causal del riesgo -como sí lo es una exclusión-, sino que es una delimitación temporal ${ }^{12}$ pues ex ante se delimita temporalmente el riesgo asegurado, en la medida en que la aseguradora establece los casos en que responderá si la reclamación se presenta durante la vigencia del seguro, en función de diversas modalidades o reglas especiales de cobertura; por ello reitera que es corolario de una estipulación que concierne a la dimensión temporaria del seguro y no a la que cobija a las causas potenciales del siniestro vinculante. Se entiende, pues, que esta modalidad es una limitación temporal y que es completamente diferente a la modalidad ocurrencia.

Es claro también que debe ser pactada para ser aplicable pues, de lo contrario, operará la modalidad por ocurrencia, ya que esta es la modalidad de cobertura por excelencia y por defecto, la que por regla general aplica en la mayoría de los casos.

Pero, frente a ella surge una pregunta: ¿el concepto de siniestro en el contrato de responsabilidad civil cambió? ${ }^{13}$ El artículo 1131 del Código establece que el siniestro en este seguro es el momento de ocurrencia del hecho externo; no obstante, la Ley 389 de 1997 no derogó esta norma. ¿Puede concluirse, entonces, que se modificó esta figura en el seguro de responsabilidad civil?

Hay algunos autores, como Andrés Ordóñez (1998, p. 126), que afirman que la Ley 389 no pretendió modificar el concepto de siniestro que ya se encuentra establecido en el artículo mencionado del Código de Comercio, sino que consideró la posibilidad de asegurar el riesgo putativo en el seguro de responsabilidad civil, porque el siniestro sigue siendo el hecho externo que ha causado el daño y que, conforme a la nueva ley, puede cubrirse siempre y cuando el asegurado desconozca que ese hecho ha ocurrido o, por lo menos, sus consecuencias dañosas.

VÁSQuez Vega (2020, p. 533) por su parte, citando la posición de la Corte Suprema de Justicia, indica que la cobertura en este tipo de seguros está circunscrita a la ocurrencia del siniestro que puede darse incluso antes de iniciar la vigencia y a la reclamación de la víctima, lo cual debe ocurrir en vigencia de la póliza. Esto permite concluir

\footnotetext{
12 De acuerdo con Fernández (2002, p. 221), el concepto de delimitación temporal de la póliza debe entenderse como aquel período durante el cual el contrato despliega sus efectos y, en consecuencia, es origen de obligaciones y derechos para las partes contratantes.

13 Si el concepto de siniestro en el seguro de responsabilidad cambió o no es una pregunta que plantean tanto la Dra. Fernández (Las cláusulas Claims made en el contrato de seguro de responsabilidad civil, 2002, p. 216) como el Dr. URIBE LozADA (El régimen general de responsabilidad de los administradores de sociedades y su aseguramiento, 2013, p. 352).
} 
que, como OrdóñEz, considera que el siniestro sigue siendo el hecho imputable al Asegurado. Para otros, no se trata de una modificación del concepto de siniestro, sino simplemente una forma de limitar la cobertura del seguro ${ }^{14}$.

Sin embargo hay otra línea de argumentación, que corresponde a la posición mayoritaria ${ }^{15}$, que considera que la noción de siniestro en los seguros de responsabilidad civil, con la modalidad Claims made sí cambió y éste ya no corresponde al hecho dañoso sino a la reclamación que hace el tercero al asegurado o al asegurador durante la vigencia de la póliza, sin que sea relevante el momento en que se dio el hecho dañoso siempre y cuando se hubiere dado durante la vigencia de la póliza o con anterioridad a ella, pero dentro del término de retroactividad pactado.

Valdría la pena preguntarse cómo conversa esta afirmación con el artículo 1054 del Código de Comercio ${ }^{16}$, pues este establece claramente que el riesgo es el suceso incierto que no depende exclusivamente de la voluntad del tomador, del asegurado o del beneficiario y cuya realización da origen a la obligación del asegurador.

Sobre esto JARAMILlo (2011, pp. 323-324) considera que sin reclamación, aunque haya ocurrido un daño previo, no habrá finalmente siniestro y por tanto, tampoco indemnización a cargo de la compañía aseguradora, motivo por el cual entre estos dos momentos hay una "estrecha relación, una especie de matrimonio, sin que ello implique una fusión o fundición".

No es unánime la posición y esa situación fue reconocida en el laudo arbitral del 2014 en el caso de Proyectar Valores S.A. Comisionista de Bolsa en Liquidación forzosa administrativa contra Chubb de Colombia Compañía de Seguros S.A. y Chartis Seguros Colombia S.A. ${ }^{17}$. Allí se pone de presente la existencia de diversas teorías pero el Tribunal decanta su decisión considerando que, al margen de la discusión enunciada, lo cierto es que la reclamación es el elemento que activa la cobertura y determina los cómputos prescriptivos.

\footnotetext{
14 Como para la profesora Mónica Fernández MuÑoz (2002, p. 222).

15 Como se ve en las obras de los profesores Juan Manuel Díaz-Granados (El seguro de responsabilidad civil, 2012), Nicolás URIBE LozADA (El régimen general de responsabilidad de los administradores de sociedades y su aseguramiento, 2013) y Carlos Ignacio JARAMILlo (Derecho de seguros, 2011).

16 Código de comercio. Artículo 1054. Definición de riesgo. Denominase riesgo el suceso incierto que no depende exclusivamente de la voluntad del tomador, del asegurado o del beneficiario, y cuya realización da origen a la obligación del asegurador. Los hechos ciertos, salvo la muerte, y los físicamente imposibles, no constituyen riesgos y son, por lo tanto, extraños al contrato de seguro. Tampoco constituye riesgo la incertidumbre subjetiva respecto de determinado hecho que haya tenido o no cumplimiento.

17 En palabras textuales se indicó: "Debe puntualizarse que en la doctrina se discute si en el sistema de reclamación hay o no un cambio de la noción de siniestro. Algunos opinan que el siniestro sigue siendo el hecho dañoso [Ordóñez], mientras otros entienden que el siniestro bajo esa modalidad es la reclamación [Jaramillo]. A nivel jurisprudencial, la Corte Suprema de Justicia, Sala de Casación Civil, se inclina por aceptar que en la modalidad claims made el siniestro es la reclamación [Fallo del 18 de diciembre de 2013 M.P. Fernando Giraldo Gutiérrez]. Al margen de la discusión enunciada lo cierto es que la reclamación es el elemento que activa la cobertura y determina los cómputos respectivos. Ahora bien, la Ley 389 de 1997 no define lo que debe entenderse por reclamación. Solo exige que sea una reclamación de la víctima en contra del asegurado o del asegurador. Por esta razón es usual que las pólizas incorporen definiciones de reclamación, las cuales han sido aplicadas sin que su validez haya sido discutida".
} 
Sin embargo es importante anotar, como lo hizo el laudo arbitral del Fondo Nacional del Ahorro en contra de Mapfre, que la modalidad de reclamación solo establece un marco conceptual para identificar la póliza de seguro o la vigencia afectada con el potencial siniestro, pero en modo alguno supone que la "Reclamación" por sí sola baste para que surja la obligación indemnizatoria del asegurador, pues será necesario que los demás elementos del seguro se cumplan; es decir que, por ejemplo, no apliquen exclusiones o que la reclamación sí haya sido realizada durante la vigencia del contrato de seguro o que el contrato de seguro no se encuentre viciado, entre otros.

Como puede verse la discusión sobre la reclamación tiene diversos efectos prácticos, como el inicio del cómputo de la prescripción mencionado y la definición de la vigencia de la póliza que debe afectarse en caso de que ocurra una reclamación pero, además, ésta permite distintas alternativas de cobertura que se expondrán a continuación ${ }^{18}$ :

1. Claims made pura: es la modalidad en donde se cubren las reclamaciones presentadas durante la vigencia del seguro, y en donde, además, los hechos que las originaron ocurrieron igualmente en la misma vigencia.

2. Claims made con retroactividad: en esta alternativa se cubren las reclamaciones presentadas al asegurado o aseguradora durante la vigencia de la póliza y que tengan su origen en hechos anteriores a la entrada en vigencia de la póliza, pues el asegurado cuenta con un período de retroactividad otorgado por la compañía aseguradora. Este período es pues un lapso previo al comienzo de la vigencia de la póliza. Con esta, como establece URiBe Lozada (2013, p. 362), se terminan cubriendo hechos pasados, pero bajo la condición de que los mismos sean desconocidos por el asegurado y no haya debido conocerlos.

Esto último no es una condición menor pues, como es sabido, los contratos de seguro buscan cubrir la materialización de riesgos y una de las características fundamentales de estos es que sean inciertos. Por ende, en los seguros en que se pacta la modalidad Claims made, siempre habrá dos elementos fundamentales relacionados con esto: i) un formulario para la suscripción del seguro en donde se debe declarar el estado del riesgo e indicar si el asegurado conoce o no la existencia de hechos o circunstancias que pudieran dar lugar a un siniestro durante la vigencia de la póliza que se va a contratar y ii) exclusiones que determinan que no habrá cobertura para aquellos hechos conocidos, que no fueron informados. Para lo demás, es decir, para las reclamaciones originadas en hechos desconocidos que hubieren ocurrido en vigencia o previos a ella pero se cuente con período de retroactividad, habrá cobertura.

Como el sistema indicado en el primer numeral, esto es el de Claims made puro, es considerado "excesivamente restrictivo", se ha considerado que la alternativa pura es realmente aquella en la que se cubren las reclamaciones realizadas en contra del asegurado por primera vez durante la vigencia de la póliza sin importar la fecha en que hubiere ocurrido el hecho que las origina, lo que significa que hay retroactividad ilimitada.

\footnotetext{
${ }_{18}$ Cada doctrinante tiene diversas formas de clasificar las distintas alternativas de cobertura: algunos con menos categorías, otros con mayor cantidad. En este documento se usará como referencia la clasificación adoptada por Nicolás URIBE LOZADA (El régimen general de responsabilidad de los administradores de sociedades y su aseguramiento, 2013).
} 
Así lo ve Nicolás URIBE (2013, p. 358) al establecer que el sistema puro de Claims made es aquel en el que se otorga retroactividad ilimitada y donde lo único que marca el siniestro es la reclamación sin que importe el momento en que ocurrió el hecho dañoso. Incluso para el profesor Daniel VÁsQuez (2020, p. 532), a falta de pacto al respecto, el seguro cuenta con retroactividad ilimitada, lo que implica que cualquier evento reclamado por primera vez dentro de la vigencia está cubierto sin importar cuándo ocurrió el hecho generador.

Esto se desprende no solo de lo restrictivo de la primera concepción de "puro" sino también de la idea de que la pureza del sistema implica que no se mezcle con otras formas de cobertura, lo que sucede con la primera alternativa descrita que combina el hecho y la reclamación.

El tribunal de arbitramento que resolvió la controversia entre Proyectar Valores S.A. Comisionista de Bolsa en Liquidación forzosa administrativa, contra Chubb de Colombia Compañía de Seguros S.A. y Chartis Seguros Colombia S.A., no obstante, puntualiza que "aunque algunas legislaciones establecen un período mínimo de retroactividad (España lo fijó en 1 año, México en 2 años y Francia impuso un período ilimitado), (...) la Ley 389 de 1997 no dispuso ningún parámetro al respecto, por lo cual, en desarrollo del principio de la autonomía de la voluntad, el período de retroactividad obedecerá a lo que acuerden los contratantes".

Además explica que, en la práctica, se encuentran cláusulas de retroactividad ilimitada, períodos de retroactividad determinados o una mezcla de ambas: período ilimitado, pero para ciertos aspectos, coberturas específicas o sublímites, una fecha de retroactividad definida.

3. Claims made con coberturas prospectivas: es posible usar herramientas para extender la cobertura hacia el futuro como el período adicional de notificaciones -también conocido como período extendido de reporte- y las cláusulas que permiten el aviso de circunstancias que puedan llegar a materializarse como siniestros ${ }^{19}$.

El período adicional de notificaciones corresponde a un beneficio que tiene el asegurado consistente en obtener cobertura para las reclamaciones que se le presenten con posterioridad a la terminación, cancelación o no renovación de la póliza. Estas reclamaciones tendrán cobertura siempre y cuando se hayan originado en hechos ocurridos durante la vigencia de la póliza o en el período de retroactividad que se le hubiere otorgado al asegurado.

Por su parte, la cláusula de aviso de circunstancias es el deber que se le otorga al asegurado de notificar los hechos o situaciones que conoció y que considera, razonablemente, que podrán materializarse en el futuro como un siniestro. Esta oportunidad que se le da al asegurado tiene asidero en que, si éste se entera de un hecho que eventualmente puede convertirse en siniestro y no lo notifica, posiblemente, cuando le reclamen en una vigencia de la póliza posterior, la compañía aseguradora se vería obligada a objetar el siniestro por ser un hecho conocido y no informado.

Incluso puede tener efectos más graves, como los consagrados en el artículo 1058 del Código de Comercio, si en el proceso de renovación el asegurado nada indica

\footnotetext{
19 Uribe LozAda (El régimen general de responsabilidad de los administradores de sociedades y su aseguramiento, 2013, p. 363) así lo considera, en aras de evitar vacíos de cobertura y desequilibrio económico del contrato de seguro de responsabilidad civil.
} 
sobre el conocimiento de tales hechos en el formulario que debe diligenciar para declarar el estado del riesgo. En cambio, si el asegurado pone de presente efectivamente esta circunstancia, la compañía aseguradora se da por enterada y en caso de que se materialice el siniestro, se afectará la vigencia de la póliza en la cual se avisó tal hecho ${ }^{20}$.

Como lo menciona Uribe LozAda (2013, p. 364), lo anteriormente descrito, más que una alternativa de la modalidad Claims made, son instrumentos utilizados para que este sistema de delimitación temporal opere en debida forma y se eviten vacíos de cobertura, a tal punto que deben considerarse como elementos de la naturaleza de los contratos de seguro de responsabilidad civil bajo esta modalidad.

Debe hacerse una aclaración importante y es que todas las alternativas descritas contemplan que la reclamación debe ser presentada al asegurado o a la aseguradora. Nótese que se trata de una disyunción: asegurado o aseguradora. Esto es importante porque en el mercado de seguros también existe el sistema Claims made and reported (reclamaciones hechas y reportadas) consistente en que, además de darse el hecho dañoso generador de la reclamación durante la vigencia o dentro del período de retroactividad y de efectuarse la reclamación al asegurado durante la vigencia de la póliza, debe también el asegurado reportar la reclamación a la compañía asegurada en este lapso de vigencia ${ }^{21}$.

Esta alternativa es altamente restrictiva y, al menos en Colombia, no debe pactarse puesto que, de acuerdo con el artículo 1081 del Código de Comercio, una vez el asegurado conoce la reclamación que le realizó la víctima, tiene dos años para presentarla a la compañía aseguradora antes de que prescriba su derecho a reclamar, por lo que realizar la reclamación a la aseguradora en el mismo lapso de la vigencia no debería ser una condición exigible para otorgar cobertura ${ }^{22}$.

\subsection{Modalidad Sunset}

Como se mencionó anteriormente, el artículo $4^{\circ}$ de la Ley 389 de 1997 no consagró únicamente la modalidad de cobertura por descubrimiento para los seguros de

\footnotetext{
20 "Normalmente al momento de la declaración del estado del riesgo mediante el diligenciamiento del formulario de asegurabilidad, se deja constancia del conocimiento de hechos y circunstancias que pudieran dar lugar a futuras reclamaciones. Dichos hechos y circunstancias declarados son expresamente excluidos por los aseguradores por tratarse de riesgos muy gravosos y prácticamente cumplidos. Cuando el informe de hechos y circunstancias conocidos se hace en el curso de una renovación del seguro de responsabilidad, lo que se generará, es que dichas circunstancias notificadas queden amparadas bajo la vigencia que expira (es decir de aquella vigencia en la que fueron notificadas a la aseguradora), pero excluidas de protección para las vigencias futuras" (Uribe Lozada, Análisis técnico - jurídico de la modalidad de cobertura por reclamación o "Claims made" en los seguros de responsabilidad civil a la luz del ordenamiento jurídico colombiano, 2016).

${ }^{21}$ Este asunto es tratado por Uribe Lozada (2016). Análisis técnico - jurídico de la modalidad de cobertura por reclamación o "Claims made" en los seguros de responsabilidad civil a la luz del ordenamiento jurídico colombiano, p. 38.

22 En palabras de VÁsquez Vega, (2020, p. 534) esta condición es ilegal porque la única consecuencia que se puede derivar del incumplimiento del deber dar aviso del siniestro es la de permitirle al asegurador deducir de la indemnización el valor de los perjuicios que le cause dicho incumplimiento, de acuerdo con los artículos 1075, 1078 y 1162 del Código de Comercio.
} 
infidelidad y la modalidad reclamación para los seguros de responsabilidad civil, sino que, además, permitió la inclusión de la modalidad Sunset. A pesar de tener poco desarrollo doctrinario, es claro que este sistema se origina en el inciso segundo de la norma mencionada.

"Se trata de un sistema de cobertura híbrido, pues conjuga la modalidad tradicional de ocurrencia con el sistema de reclamación. Aquí pues se exige que los hechos ocurran dentro de la vigencia de la póliza y además, que la reclamación se presente en un período establecido (que no podrá ser menor a dos años). Es decir, el siniestro no es propiamente el hecho dañoso imputable al asegurado, como en la modalidad ocurrencia, y tampoco será la reclamación presentada al asegurado o aseguradora, como en la modalidad reclamación vista en líneas anteriores, sino que el siniestro se compone de la mezcla de estos dos elementos"23. Su nombre, Sunset, se debe a que si no llega a producirse el reclamo de la víctima o beneficiaria del seguro en el término máximo pactado, se produce el "ocaso" de la cobertura ${ }^{24}$.

Luego de entender las razones por las cuales se creó la modalidad de cobertura por reclamación o Claims made, su inclusión en el ordenamiento jurídico colombiano a partir de la Ley 389 y las distintas alternativas de cobertura que se derivaron del artículo $4^{\circ}$ de tal ley, sus características, operatividad y efectos, vale la pena exponer lo que para la doctrina son las ventajas y desventajas de la modalidad de cobertura sobre la que se ha hablado a lo largo de estas líneas y se analizará si, de conformidad con todo lo establecido hasta ahora es posible indicar la naturaleza de la modalidad, es decir, si es legal y aplicable o si, por el contrario, al tratarse de una modalidad de limitación de cobertura, no debe pactarse, o si podría considerarse ilegal o de alguna forma podría ser abusiva.

Ventajas:

1. Con esta modalidad se mitiga para las aseguradoras el efecto que tenían los riesgos de cola larga. Frente a esto el Dr. Carlos Ignacio JARAMiLlo (2011, pp. 348349) indica que:

“... la aseguradora o la reaseguradora pueden tener la tranquilidad de que su obligación de pagar la correspondiente indemnización solamente se podrá hacer efectiva en el período de vigencia de la póliza o, a lo sumo, en el lapso retrospectivo o ultractivo que sea pactado en desarrollo del contrato, pero no podrá ir más allá, como quiera que la delimitación temporal generará que por fuera de ese lapso no exista responsabilidad alguna en cabeza de la entidad aseguradora."

A pesar de lo anterior, en la práctica, es posible que los asegurados, durante el período adicional de notificaciones, le comuniquen a la aseguradora circunstancias; es decir que la póliza ya no está vigente, pero se otorgó un período de reporte extendido y en ese plazo el asegurado conoció algún hecho el cual considera que razonablemente puede convertirse en un siniestro.

\footnotetext{
23 Díaz-Granados, Juan Manuel (2012). El seguro de responsabilidad civil. Editorial Universidad del Rosario y Pontificia Universidad Javeriana, Facultad de Ciencias Jurídicas, p. 182.

24 Uribe Lozada, Nicolás. (2013). El régimen general de responsabilidad de los administradores de sociedades y su aseguramiento. Pontificia Universidad Javeriana, Facultad de Ciencias Jurídica. Grupo Editorial Ibáñez, p. 394.
} 
Lo anterior elimina de forma inmediata la ventaja manifestada en este numeral pues nuevamente prolonga indefinidamente la cobertura del seguro, ya que al ser éste un mero aviso de circunstancia, no puede prescribir pues no se ha configurado todavía un derecho para el Asegurado de reclamar. En ese sentido, pueden pasar muchos años sin que tal hecho efectivamente se materialice en una reclamación, razón por la cual la aseguradora tendrá, durante un período de tiempo indeterminado, una exposición a un riesgo que ya le ha sido notificado con anterioridad y que no puede excluir ni dejar sin cobertura cuando efectivamente se convierta en un siniestro.

Lastimosamente sobre esta situación que puede presentarse no existe doctrina al respecto y tampoco pronunciamientos judiciales, pero definitivamente puede ocurrir a menos que en la cláusula que otorga el período adicional de notificaciones se indique expresamente la imposibilidad de realizar avisos de circunstancias durante ese lapso. Luego, habrá que determinar si es viable para las aseguradoras hacer este tipo de aclaraciones o si esto podría considerarse una práctica indebida.

2. La modalidad de cobertura por reclamación o Claims made permite identificar con facilidad cuál es la vigencia de la póliza que se debe afectar en aquellos casos en que el hecho dañoso y la generación del perjuicio no coinciden en el mismo instante o cuando existen hechos continuados que ocurren en vigencia de varias pólizas.

Como se podrá evidenciar más adelante, en algunos fallos recientes la Contraloría General de República ha desconocido esta característica de la modalidad y, en cambio, aplica el principio del "deep pocket" consistente en que, como lo indicó URIBE LOZADA (2013, p. 371), ante la dificultad de seleccionar una póliza de seguro que afectar para proteger a las víctimas y al Asegurado, se decide afectarlas todas haciendo solidariamente responsables a todas las aseguradoras o pólizas que se hubieran contratado entre el daño y la fecha de reclamación. Incluso, llegaron al extremo de acumular todas las sumas aseguradas de las diferentes pólizas existentes como una medida aún más garantista de los intereses del asegurado y las víctimas.

3. Entendiendo que el siniestro bajo esta modalidad de cobertura es la reclamación, queda claro que es a partir de éste el momento en que debe iniciar el cómputo de la prescripción. Bajo la modalidad tradicional de ocurrencia hay un vacío pues el término empieza a contarse desde la ocurrencia del hecho, pero si los perjuicios se presentan posteriormente a los dos o cinco años de la prescripción, la víctima se queda sin acción frente a la aseguradora.

4. La posibilidad de otorgar períodos de retroactividad es, sin duda, uno de los beneficios más importantes que trae esta modalidad de cobertura. Este beneficio se entrega a los asegurados para poder cubrir hechos pretéritos que el Asegurado desconozca y que se materialicen en reclamaciones posteriores realizadas durante la vigencia del seguro. Como lo menciona Uribe LozAda (2013, p. 375), se recortó la responsabilidad futura del Asegurado a cambio de asumir responsabilidad por los hechos del pasado.

Esto permite no solo sanear los vicios que pudo cometer el Asegurado en el pasado sino también evitar vacíos de cobertura por una contratación de seguros con diferentes modalidades o no haberlos contratado a tiempo. 
5. En relación con la ventaja mencionada en el numeral primero, se genera una ventaja para los asegurados pues el valor de las primas de las pólizas pactadas bajo esta modalidad es menor que el que podría obtenerse para el mismo riesgo bajo la modalidad ocurrencia. Esto se da pues al reducirse la incertidumbre y, en consecuencia, el costo para las aseguradoras por no tenerse que constituir reservas por períodos tan largos se puede disminuir el precio del seguro.

\section{Desventajas:}

1. Gran parte de la doctrina ha considerado que las cláusulas Claims made implican una desprotección del consumidor. Para la Dra. Fernández (2002, pp. 232-233) éstas implican un vacío en la cobertura aun cuando los asegurados hubieren realizado una contratación continua de sus seguros de responsabilidad y las considera una forma liberal para que las aseguradoras puedan limitar sus compromisos dentro del contrato de seguro de responsabilidad civil.

El profesor Nicolás URIBE (2013, p. 378) indica que la doctrina es prácticamente unánime al afirmar que el sistema Claims made, al reducir sustancialmente la exposición temporal de los aseguradores, deja en muchos casos casi que desprotegidos a los consumidores, pues habrá una mayor propensión para que ciertos hechos se queden huérfanos de cobertura y conviertan en nugatoria la prestación indemnizatoria a cargo del asegurador.

Por su parte Carlos Ignacio Jaramillo (2011, pp. 152-154) manifiesta que la víctima y el asegurado se pueden encontrar desprotegidos especialmente si se pacta la más angosta de las modalidades puras de Claims made y también que esta ha generado las más diversas reacciones, tanto de la academia como de la judicatura y del propio legislador, por lo que no pueden mencionarse únicamente las bondades de la modalidad, pues claramente esta entraña un notorio recorte de cobertura; pero tampoco puede satanizarse sino tratarla como una realidad del sistema jurídico colombiano ${ }^{25}$.

Parte de la doctrina considera, por el contrario, que no se trata de un sistema tan cerrado ya que es posible estipular coberturas retroactivas o ampliar los plazos de las reclamaciones aunque la póliza se haya extinguido (con el período adicional

\footnotetext{
25 Jaramillo, Carlos Ignacio. (2011). Derecho de seguros. Editorial Temis y Pontificia Universidad Javeriana. Bogotá, p. 378. Sobre este particular también menciona que se puede llegar a hablar de la desnaturalización del contrato y que otras partes de la doctrina incluso han aludido a una "meridiana abusividad negocial". Adicionalmente que "hay quienes se refieren a que ellas se tornan ilusorias (Genevieve VINEY), peligrosas (Iyvonne LAmbert) y onerosas (Fernando SÁnChez Calero). Y otros expresan que con ellas se desatiende a los asegurados (María DE los Ángeles CALZADa), que ellas se erigen en la concesión injustificada de una ventaja sin predecentes para el gremio asegurador, gravemente atentatoria contra el derecho de los asegurados, aun en condiciones en que, daos los términos de prescripción de las acciones de responsabilidad civil extracontractual (Andrés OrDónez), que ellas afectan las expectativas del asegurado y la víctima (Luis Alberto Botero, Patricia Jaramillo y Fernando Rodas), que son ilícitas (Rubén Stiglitz), diabólicas (Waldo Sobrino) desastrosas (Muriel CaGny y Lous Perdrix), un engendro jurídico (Fernando REgLero CAMPOS), una trampa creada por los aseguradores que hace peligrar a la propia institución del seguro de responsabilidad civil, cuya preceptiva es una barbaridad técnica y hasta un atentado contra el buen castellano (Mariano IzQuIERDo ToLSADA), entre otros adjetivos.
} 
de notificaciones, por ejemplo) ${ }^{26}$. Otros, en cambio, los ven como un "mal necesario" pues sin su presencia sería imposible obtener cobertura de responsabilidad civil para ciertas actividades como se ha mencionado en apartes anteriores ${ }^{27}$.

2. Una de las grandes desventajas de la modalidad es el problema del cliente cautivo $^{28}$, que puede materializarse de dos formas: i) el asegurado se verá obligado a renovar su seguro de responsabilidad civil, por temor a quedarse sin cobertura ante futuras reclamaciones que le pueden realizar en razón de hechos ocurridos en el transcurso de su actividad y ii) será casi imposible para el asegurado cambiar de compañía aseguradora aún si se encuentra insatisfecho con el servicio brindado, pues esto supondrá vacíos o lagunas de coberturas, como lo presentó Mónica Lucía FERNÁNDEZ (2002, p. 231).

3. Otra de las desventajas consideradas por la doctrina es la posibilidad de fraude por parte del asegurado en contra de la aseguradora, en relación con el conocimiento de los hechos o circunstancias generadoras de la reclamación. Esto es que los Asegurados podrían presentar reclamaciones a las aseguradoras, originadas en hechos que estos ya conocían, argumentando su desconocimiento ${ }^{29}$.

4. Para la Dra. Fernández (2002, p. 233), puede ser esta modalidad una forma de que las aseguradoras, con mala fe, decidan no renovar las pólizas de sus clientes cuando se enteran de la ocurrencia de algunos hechos que todavía no han sido objeto de reclamaciones, pero que podrían ser siniestros posteriormente.

Como consecuencia de todo lo anterior, se ha mencionado por algunos doctrinantes que estas cláusulas son abusivas, que son un claro atentado en contra de la buena fe de los asegurados, que generan un claro desequilibrio contractual, muestran una asimetría de las prestaciones e implican un abuso de la posición dominante por parte de las aseguradoras ${ }^{30}$.

Frente a las diversas opiniones que esto genera, la postura de Miranda SuÁrez (2001, p. 113 citado en Uribe LozAdA, Nicolás. 2013, p. 379) frente al tema es relevante:

“... la delimitación de la cobertura con arreglo a criterios que incorporan la reclamación como elemento del siniestro es un adecuado y legítimo medio de seguridad frente a los siniestros tardíos, pero su aplicación estricta resulta de una rigidez excesiva de ahí que su viabilidad y eficacia deba producirse en combinación con otros principios como el de ocurrencia y sea de vital importancia para su validez y correcta estipulación de un razonable período de cobertura ya sea retroactivo, ya sea post contractum".

\footnotetext{
26 Ver PaVelek Zamora, Eduardo. Delimitación temporal en el seguro de responsabilidad civil la nulidad del “claims made” ¿otra vuelta a la tuerca? Gerencia de riesgos, num. 41, Fundación Mapfre Estudios, p. 43.

27 Tal como lo describe Nicolás Uribe (2013, p. 349).

${ }_{28}$ Así lo denomina Nicolás URIBE en El régimen general de responsabilidad de los administradores de sociedades y su aseguramiento. Pontificia Universidad Javeriana, Facultad de ciencias jurídicas. Grupo Editorial Ibañez. Bogotá. 2013, p. 385.

29 Este hecho lo manifiesta Nicolás Uribe (2013, p. 392) y Mónica Lucía Fernández (2002, p. 232) indicando con el aseguramiento del riesgo putativo es posible que se presenten fraudes por parte de los asegurados, en el sentido de que incurran en reticencia o en ocultamiento de conocer hechos anteriores al contrato y que den lugar a reclamos dentro de él.

30 De esta forma se expresó Mónica Lucía Fernández (2002, pp. 233-234).
} 
En cualquier caso, es necesario hacer hincapié en la legalidad de estas y resaltar que a pesar de consistir en una limitación temporal de la cobertura, esto por sí solo no las hace abusivas, especialmente si se considera que esta modalidad puede pactarse y no es obligatoria, que tiene mecanismos adicionales que se pueden estipular para proteger al asegurado y a la víctima, como los períodos de retroactividad, el aviso de circunstancias, el período extendido de reportes, y que, a diferencia de lo anterior, esta modalidad no está llamada a cubrir hechos, sino reclamaciones y en todo caso, no es obligatorio que deba cubrirlas todas.

El artículo 1056 del Código de Comercio establece que las aseguradoras son libres de elegir los riesgos que desean suscribir y, en este sentido, incluso en la modalidad tradicional de ocurrencia existen las exclusiones, lo que demuestra que ni siquiera ella cubre todos los hechos ocurridos imputables al asegurado que generen perjuicios a un tercero, por lo que no es posible afirmar que la modalidad por reclamación debería proveer cobertura absoluta.

Es posible que el artículo $4^{\circ}$ de la Ley 389 no haya sido muy claro y su redacción no hubiera sido muy afortunada, por lo que es importante que coexistan los siguientes elementos mínimos en un seguro pactado bajo la modalidad de cobertura Claims made o reclamación, para un adecuado funcionamiento de este sistema:

1. Período de retroactividad que se amplíe con cada renovación para que se dé cobertura a las reclamaciones que surjan de hechos originados desde la entrada en vigencia de la primera póliza.

2. Que no se exija al asegurado notificar a la aseguradora la reclamación que le presentó la víctima en un tiempo establecido, pues para esto cuenta con los términos establecidos por el Código de Comercio.

3. Posibilidad para el asegurado de obtener un período adicional de notificaciones para cubrir las reclamaciones futuras que puedan presentarle, en caso de haber culminado la vigencia de la póliza.

4. Inclusión de la cláusula que permita al asegurado avisar a la compañía aseguradora sobre hechos o circunstancias que conoció y que considera, razonablemente, que pueden conllevar a un siniestro en el futuro.

\section{POSTURA DE LA CORTE SUPREMA DE JUSTICIA}

La Corte Suprema de Justicia (en adelante CSJ) se ha pronunciado sobre la modalidad de cobertura Claims made en diversos fallos. En algunas ocasiones simplemente menciona que la póliza sobre la que versa el litigio está pactada bajo tal modalidad, en otras recalca que esta modalidad tuvo su origen con la expedición de la Ley 389 de 1997 y, en otras oportunidades, entra en detalle a desarrollar lo que esta modalidad significa, sus efectos y modos de aplicarse.

Como se observará más adelante, el tema ha sido controversial a tal punto de existir salvamentos de voto y aclaraciones de los magistrados Ariel Salazar y Luis Armando 
Tolosa, quienes consideraron que esta modalidad, a pesar de tener consagración legal, es abusiva y, por tanto, cuestionan su uso y aplicación. No obstante, los mismos magistrados, en fallos posteriores, guardaron silencio.

Sobre los orígenes de la modalidad de cobertura Claims made, el magistrado Aroldo Wilson Quiroz, actuando como ponente en sentencia del 18 de julio de 2017 (SC103002017, Exp. 76001310300120010019201), explicó que en la ponencia para segundo debate del proyecto de ley número 65 de 1995 se justificó su necesidad ya que, como se mencionó en capítulos previos, era necesaria una modernización de las normas de seguros para cubrir ciertos riesgos y, así mismo, acoger las tendencias mundiales del mercado reasegurador para los seguros de responsabilidad y manejo. Lo anterior, indicó la CSJ, tenía fundamento en que los contratos de seguro, especialmente los de responsabilidad, se estaban volviendo inviables para las compañías de seguro pues su suscripción bajo la modalidad de cobertura tradicional implicaba asumir riesgos por mucho tiempo, lo cual suponía retenciones o primas excesivamente altas.

En múltiples fallos la CSJ reitera que la modalidad de cobertura Claims made se encuentra en el ordenamiento jurídico colombiano en virtud del artículo $4^{\circ}$ de la Ley 389 de 1997 y transcribe lo establecido por esta norma ${ }^{31}$. En otros fallos, como el del 15 de diciembre de 2006 (M.P. Jaime Arrubla Paucar, Exp. 52001310300420000027601) y del 30 de octubre de 2007 de la magistrada Ruth Marina Díaz (Exp. 05001310300820020056501), la Corte simplemente reconoce que la modalidad de cobertura del seguro sobre el que versa el litigio que se está resolviendo es Claims made, sin profundizar ni entrar en detalle sobre esta forma de limitar la cobertura, pues por motivos de técnica de casación se abstuvo de pronunciarse al respecto. No obstante, podría entenderse que la CSJ en esta temprana etapa consideraba la modalidad de natural aplicación en el derecho de seguros colombiano.

Igualmente, el 9 de agosto de 2010 (M.P. Jaime Arrubla Paucar, Exp. $11001310304320040052401)$ se analizaron los hechos considerando adecuado el pacto de la modalidad Claims made en el seguro sobre el cual versaba la disputa, se recalca la legalidad de esta y, por lo mismo, no se discute si son aplicables o legales.

Rápidamente entonces se puede concluir que la CSJ y, en términos generales, la jurisdicción ordinaria, reconoce la legalidad de esta modalidad de cobertura en Colombia y, en consecuencia, no se oponen a su uso y aplicación, pues entienden que es una alternativa que la ley contempla y permite para los seguros de responsabilidad civil.

Lo anterior incluso se puede ver en sedes de primera y segunda instancia, tal como lo muestran los fallos de casación cuando hacen un recuento lo establecido por el a quo y el ad quem en tales etapas procesales. Allí se evidencia que incluso en juzgados y

\footnotetext{
31 Sentencia del 15 de diciembre de 2006. MP: Jaime Alberto Arrubla Paucar. Expediente No. 5200131-03-004-2000-00276-01; Sentencia del 9 de agosto de 2010. MP: Jaime Arrubla Paucar. Expediente: 11001310304320040052401; Sentencia del 18 de diciembre de 2013. MP: Fernando Giraldo Gutiérrez. Exp. 1100131030412000-1098-01; Sentencia del 31 de julio de 2014. Magistrada Ponente: Ruth Marina Díaz Rueda. SC10048-2014. Radicación n 11001-3103-015-2008-00102-01; Sentencia del 18 de julio de 2017. MP: Aroldo Wilson Quiroz. SC10300-2017, Exp. 76001-31-03-001-2001-00192-01; Sentencia del 03 de diciembre de 2019. Magistrado Ponente: Luis Alonso Rico Puerta. Radicado: 11001310301520080010201.
} 
tribunales se entiende que esta modalidad existe en Colombia, que tiene consagración legal y que, por tanto, tiene plena aplicabilidad, a pesar de que, tal vez, no en todos los casos el entendimiento de cómo funciona esta modalidad sea el más técnico o adecuado.

Por otro lado, partiendo de la misma transcripción que hace la CSJ el 31 de julio de 2014 (M.P. Ruth Marina Díaz, SC10048-2014, Exp. 11001310301520080010201) del artículo tantas veces mencionado, puede inferirse que esta entidad reconoce que la cobertura en los seguros en que se pacta esta modalidad de cobertura, se circunscribe a las reclamaciones formuladas por el damnificado al asegurado o a la compañía durante la vigencia, "[...] así se trate de hechos ocurridos con anterioridad a su iniciación" y que también se entenderán cubiertos "los hechos que acaezcan durante la vigencia del seguro de responsabilidad siempre que la reclamación del damnificado al asegurado o al asegurador se efectúe dentro del término estipulado en el contrato, el cual no será inferior a dos años".

En el primer caso, de acuerdo con lo mencionado en capítulos previos, la CSJ se refiere a la modalidad Claims made propiamente y en el segundo, se desvía un poco haciendo referencia a la modalidad de cobertura Sunset, signo tal vez de que la CSJ en ocasiones no diferencia una modalidad de otra, tema sobre el que se volverá más adelante.

Desde el $2010 \quad(09 / 08 / 2010$, M.P. Jaime Arrubla Paucar, Exp. $11001310304320040052401)$, en proceso iniciado por la Fiduciaria Cafetera S.A - Fiducafé en contra de la Previsora S.A. en el que solicitaban cobertura de la responsabilidad civil profesional amparada en su seguro global bancario, la CSJ, aun cuando no mencionó expresamente algún problema relacionado con las cláusulas Claims made ni su consagración legal o aplicación, sí utilizó como argumentos para no casar la sentencia la falta de reclamos de terceros para originar el siniestro, señal de que la Corte reconocía la importancia de la reclamación en esta modalidad y en este tipo de seguros y coberturas.

En uno de los fallos más relevantes sobre este asunto, la CSJ el 18 de diciembre de 2013 (M.P. Fernando Giraldo Gutiérrez, Exp. 1100131030412000109801), al resolver el recurso de casación interpuesto por los demandantes, reconoció que en los seguros que utilizan cláusulas Claims made "la cobertura está delimitada temporalmente por distintas modalidades y combinación de cláusulas", que debe producirse la reclamación durante la vigencia de la póliza y presentó una corta e ilustrativa explicación sobre las posibles situaciones que surgen de usar tal modalidad de cobertura en un contrato de seguro. Específicamente mencionó que aquello que puede ocurrir es lo siguiente:

“a) Que coinciden dentro de la vigencia tanto el hecho dañoso, como la reclamación de la víctima al asegurado o aseguradora.

b) Que el hecho dañoso sea anterior a la vigencia, pero el reclamo se presente dentro de ésta.

c) Que se cubran sucesos acaecidos durante la vigencia, pero el reclamo se haga por fuera de la misma, en un plazo preestablecido para notificaciones".

Indica, además, que lo establecido en el literal a) es "connatural al convenio", mientras que las otras dos situaciones, esto es, lo mencionado en los literales b) y c), 
"requieren de pactos expresos claramente delimitados", todo lo cual coincide con los distintos puntos de vista de la doctrina sobre la modalidad Claims made mencionados en apartados anteriores.

Ese mismo entendimiento tuvo la Dra. Ruth Marina Díaz Rueda en su fallo de 2014 (SC10048-2014, Exp. 11001310301520080010201) pues al examinar la disposición del artículo $4^{\circ}$ de la Ley 387 en relación con la oportunidad del reclamo presentado por la Cámara de Comercio de Bogotá en contra de La Previsora, citó textualmente la sentencia expuesta en líneas anteriores y con base en ella consideró que el supuesto de la controversia que estaba resolviendo se adecuaba a la segunda hipótesis, "toda vez que el hecho perjudicial aconteció el «2 de agosto de 2004» al efectuarse el «registro del acta de aprobación de la liquidación de la sociedad Luz de Bogotá S.A.»", momento en el cual no estaba vigente la póliza, pero sí se tenía contemplado un período de retroactividad, "en tanto que el «reclamo a la asegurada» se realizó hallándose en vigor el «contrato de seguro»"“.

Por su parte, en sentencia del 18 de julio de 2017 (M.P. Aroldo Wilson Quiroz, SC10300-2017, Exp. 76001310300120010019201), la CSJ citó nuevamente el fallo del 2013 mencionado ampliando un poco su explicación al indicar que, si bien de conformidad con el artículo 1131 del Código de Comercio el siniestro en el seguro de responsabilidad civil se entendía ocurrido en el momento del acaecimiento del hecho externo imputable al asegurado, quedando cubierto por la póliza vigente para dicho momento, a partir de la ley 389 mencionada se permitió limitar temporalmente la cobertura o extenderla a hechos ocurridos con anterioridad a la vigencia de esta, siempre que la reclamación llegara en vigencia de la póliza.

Sin embargo, indicó que esto no significaba que el requerimiento fuera requisito para que se configurara el siniestro pues, en su sentir y tal como lo manifiesta el artículo 1131 del Código, el daño es suficiente para la configuración del siniestro, solo que si la modalidad del seguro es Claims made, se hace exigible que la reclamación judicial o extrajudicial llegue al asegurado en vigencia de la póliza.

Esto indica que para la CSJ en este fallo el doble criterio debe agotarse siempre para que nazca la obligación de indemnizar, pero interpreta que ello no significa que el siniestro sea un acto complejo pues, recalca, la presentación de la reclamación no es el siniestro ni hace parte de él, solo es una condición adicional en estos seguros.

En este punto la CSJ le da una relevancia importante al hecho dañoso y, en cambio, a la reclamación que llegue dentro de la vigencia de la póliza la considera un ingrediente más para que se otorgue la indemnización por parte de la aseguradora ${ }^{32}$.

En cambio, en el 2019 la CSJ (03/12/2019, M.P. Luis Alonso Rico Puerta, SC52172019, Exp. 11001310301520080010201) parece volver a la teoría mayoritaria indicando que para la aseguradora "no es trascendente el momento en el que acaezca el hecho externo imputable al asegurado", pues es perfectamente posible que sean

\footnotetext{
32 Esta es la posición que habían adoptado el doctrinante Andrés Ordóñez y el profesor Bernardo Botero y que se expuso en el capítulo correspondiente.
} 
indemnizados detrimentos patrimoniales por hechos ocurridos antes del inicio de vigencia, siempre y cuando la reclamación se presente durante la vigencia.

No obstante, para soportar esta afirmación cita la sentencia del 2017 y reafirma que la exigencia de la reclamación para afectar la póliza es un requisito adicional que debe agotarse en todos los casos para el nacimiento de la obligación resarcitoria de la compañía aseguradora y que, por tanto, en este tipo de pólizas es necesario que se den dos eventos relevantes: i) el hecho imputable al asegurado y, ii) la reclamación formulada por el damnificado al asegurado o directamente a la aseguradora.

Pues bien, es cierto que para que surja la responsabilidad civil es necesario que se dé un hecho dañoso imputable al asegurado y que genere unos perjuicios para el tercero; sin embargo, estas dos últimas posturas de la CSJ indican que consideran que el siniestro sigue siendo tal hecho, por lo que será fundamental que este ocurra, pero que no es relevante el momento en que esto suceda, pues la reclamación al asegurado o asegurador tiene que darse obligatoriamente para que opere la cobertura, pero esta solamente es un requisito adicional.

Como se ha dicho, esta no es la posición o interpretación mayoritaria de la doctrina y del mercado asegurador, pues para estos la reclamación no es un simple requisito adicional sino el siniestro en sí mismo.

Se rescata de este pronunciamiento del 2019, que la CSJ identificó cómo el artículo $4^{\text {o }}$ de la ley 389 tantas veces mencionada, permitió tanto la modalidad Claims made como la modalidad Sunset ${ }^{33}$.

Puede concluirse entonces que la CSJ comprende la legalidad de la modalidad reclamación $y$, por ende, permite su aplicación de forma natural en los contratos de seguro de responsabilidad civil. También que, si bien ha tenido diversas interpretaciones sobre los elementos fundamentales de ella, como cuál es el siniestro en esta modalidad, es cierto que son interpretaciones que incluso han sido presentadas por la doctrina y que, finalmente, no tienen efectos prácticos disímiles.

Eso sí, no ha desarrollado la CSJ de forma completa el alcance y desarrollo de la modalidad Claims made como sí lo ha hecho la doctrina nacional. Y por ende no ha profundizado, por ejemplo, en los períodos adicionales de notificación, ni en las cláusulas de aviso de circunstancias, y tampoco ha diferenciado, a profundidad, la modalidad Claims made de la modalidad Sunset.

\footnotetext{
33 El fallo estableció lo siguiente: "Esa norma franqueó el paso a dos tipologías negociales distintas al tradicional seguro basado en la ocurrencia. En la primera de ellas, la aseguradora se obliga a mantener indemne el patrimonio del asegurado frente a la responsabilidad originada en un hecho externo que le sea imputable, sin importar la época de su ocurrencia, siempre y cuando la víctima del evento dañoso formule la reclamación al asegurado o al asegurador, durante la vigencia de la póliza (modalidad Claims Made).

En la segunda, la aseguradora asume la protección del patrimonio del asegurado frente a débitos relacionados con un hecho externo que le sea imputable, siempre y cuando i) ese hecho externo sobrevenga en vigencia de la póliza y ii) la víctima del evento dañoso formule reclamación al asegurado, o al asegurador, dentro de un lapso convenido, contado a partir de la expiración del término contractual, y que no puede ser inferior a dos años (modalidad de ocurrencia Sunset)".
} 


\subsection{Los salvamentos de voto}

Como ya se dijo la CSJ ha emitido fallos en los que se pronuncia sobre la modalidad de cobertura Claims made para resolver los casos de los que conoce, desarrollando cómo funciona tal modalidad y cómo debía ser aplicada en cada uno de los casos concretos. Más allá de si lo hace de forma técnica y adecuada, lo que se puede concluir es que, para la jurisdicción ordinaria y en específico para la CSJ, esta modalidad de cobertura es legal y debe ser aplicada en el ordenamiento jurídico colombiano en los casos en que así se haya pactado entre la compañía aseguradora y el tomador o asegurado del seguro particular.

A pesar de esto los magistrados Ariel Salazar y Luis Armando Tolosa expusieron sus salvamentos de voto en la sentencia del 18 de diciembre de 2017 con ponencia del magistrado Aroldo Wilson Quiroz. Por la vehemencia de estos y la interpretación de la modalidad completamente opuesta a la línea que consistentemente llevaba la CSJ y la doctrina, serán expuestos a continuación.

En el salvamento de voto del Dr. Ariel Salazar Ramírez, en términos generales hay que resaltar que este consideró que la modalidad Claims made desnaturaliza la institución del seguro y viola los derechos de los consumidores de seguros, así:

"Admitir la validez de estas cláusulas supone desconocer la finalidad del seguro de
RC respecto del asegurado y el beneficiario pues este último tendría que asumir las
consecuencias nocivas de un convenio en el que no participó y el asegurado vería
afectado su patrimonio ante una situación que no le es atribuible, como lo es el re-
clamo extemporáneo de la víctima. De ese modo, al desaparecer el propósito de este
contrato según lo establecido por el artículo 1127 del Código de Comercio, faltaría
uno de sus elementos esenciales, lo que lo haría ineficaz en los términos del artículo
898 ibídem, pues toda cláusula que tienda a aminorar la función del contrato de seguro
o a reducir la duración de la cobertura de la responsabilidad civil carece de causa, es
ilícita y debe reputarse como no escrita".

Igualmente, manifiesta que "la mencionada modalidad aseguraticia atiende exclusivamente al interés de las aseguradoras porque crean una ventaja ilícita a su favor y se erigen en un instrumento violatorio de los derechos de los asegurados y los perjudicados, dado que acaban con la esencia del contrato de seguro".

Frente a lo anterior hay que advertir que el magistrado incurre en muchas imprecisiones, ya que la afectación del patrimonio del asegurado surge por la generación del daño a un tercero, no por una reclamación extemporánea del beneficiario. A su vez, el beneficiario al que hace referencia, en primer lugar, no hace parte del contrato de seguro en estricto sentido, como lo establece el artículo 1037 del Código de Comercio y, además, no es más que la víctima de un perjuicio, por lo cual este continuará contando con la acción de responsabilidad civil para reclamar su indemnización; por ende no se puede afirmar que este debe asumir consecuencias nocivas en razón de un contrato de seguro pues su acción principal para reclamar seguirá existiendo, independientemente de que el contrato de seguro tenga una modalidad de cobertura $\mathrm{u}$ otra o, incluso, de si existe o no un seguro. 
El propósito al que parece hacer referencia el magistrado es la obligación condicional del asegurador de indemnizar a la víctima para resarcir los perjuicios sufridos. Esta modalidad de cobertura no elimina esta obligación, pues como se ha visto, lo que hace es una delimitación temporal de la cobertura y, por ende, ningún elemento esencial del contrato de seguro desaparece.

El Dr. Ariel Salazar establece, por primera vez, que las cláusulas Claims made son ilícitas, carecen de causa y se deben entender como no escritas, lo cual, como se ha visto, no había sido la posición de la CSJ en ninguno de sus fallos

¿Cómo puede establecerse que una modalidad de cobertura que está consagrada en la Ley es ilícita? Se volverá sobre este punto más adelante.

Indicó también, como lo habían hecho otros magistrados en los fallos expuestos con anterioridad, que el siniestro para esta modalidad de cobertura es el hecho, frente a lo cual aplican las mismas observaciones realizadas previamente. No obstante, el Dr. Salazar utiliza este argumento para afirmar que, si además a este se le incorpora una cláusula que lo condicione al término de vigencia de la póliza, “(...) cambia la definición de riesgo asegurado, pues ya no es un hecho externo imputable al asegurado, sino, además, la reclamación realizada por el asegurado, hecho voluntario y no externo, lo que cambia la naturaleza del seguro de RC".

Sobre este particular hay que reconocer que, en efecto, la reclamación es un hecho voluntario y externo; pero afirmar que el único siniestro posible en los seguros de responsabilidad civil es el acaecimiento del hecho imputable al asegurado, es desconocer por completo el origen y las razones por las cuales esta modalidad fue creada e introducida a nuestro sistema.

Frente a ello el magistrado afirma que la justificación de estas cláusulas desaparece ya que la razón de ser de ellas era reducir la prescripción, lo que se logró con la ley 791 de 2002 y esto nuevamente muestra que se desconoce el fondo de las situaciones suscitadas en el mercado asegurador en los años 80, pues evidentemente esta modalidad no pretendía modificar los términos de prescripción.

También afirmó el magistrado que "el riesgo se traslada no a la aseguradora sino al asegurado, pues este tendría que realizar la reclamación dentro del plazo impuesto", y sobre ello hay que anotar los errores de interpretación en los que incurre. En primer lugar, el asegurado, una vez conoce la reclamación que a él le hizo la víctima del presunto daño, tendrá dos años para reclamarle a la compañía aseguradora en virtud de la prescripción del artículo 1081 del Código de Comercio para los contratos de seguro. Esto confirma que no es una condición de la modalidad de cobertura Claims made que el asegurado reclame en un plazo impuesto, como se afirma en el salvamento de voto. En segundo lugar, está mezclando la modalidad de cobertura Claims made con la denominada Sunset.

Y finaliza su intervención considerando lo siguiente:

"Las cláusulas de "reclamo hecho" son abusivas, rompen el equilibrio contractual, vulneran los derechos del usuario o consumidor de seguros y lo dejan en estado de 
indefensión, contraviniendo la tendencia mundial de protección al tomador, el asegurado y el beneficiario, quienes no tienen la posibilidad de oponerse a ellas o no contratarlas por cuanto van incorporadas en el contrato de adhesión; debiendo financiar con su patrimonio los daños que causan a pesar de estar asegurados, bajo el pretexto de que las víctimas tardaron en presentar su reclamación. Las aludidas cláusulas, en fin, constituyen un retroceso en materia de protección al consumidor de seguros y son un obstáculo al principio de reparación de los daños a las víctimas.

Además de ello, alteran el sistema de la responsabilidad civil, en la medida que el responsable (médicos, empresarios, ciudadanos del común) ven afectado injustamente su patrimonio al tener que pagar unas sumas de dinero que aseguraron mediante una póliza completamente ineficaz al propósito del seguro".

A pesar de que ya se han realizado comentarios sobre estas expresiones, vale la pena reiterar algunos de estos aspectos:

1. El magistrado Salazar indica que esta modalidad implica una violación al derecho del consumidor. Esta tesis, como se ha visto, es compartida por alguna parte de la doctrina pues el hecho de pactarla tiene algunos efectos como los planteados en los capítulos preliminares, pues suponen una delimitación temporal de cobertura.

2. Sin embargo olvida lo estatuido en el artículo 1131 del Código de Comercio pues, en virtud de la norma citada, el beneficiario tendrá diez años para reclamarle al asegurado, gracias al término de prescripción de la acción civil. El asegurado, a su vez, tendrá dos años adicionales para reclamarle a la compañía aseguradora, pues en el momento en que la víctima le reclama conoce por primera vez. Esto en la práctica lo que implica es que se amplíe el término de la reclamación hasta los doce años, lo cual no ocurre en ninguna otra modalidad de cobertura. Lo anterior deja sin fundamento sus argumentos de "abusivos, desequilibrio contractual, y vulneración de los derechos de los consumidores".

3. Desconoce la legalidad de la modalidad de cobertura. Es claro que esa modalidad de reclamación tiene consagración legal, como tantas veces se ha reiterado. Entonces, ¿cómo puede indicar que esta modalidad es abusiva? La abusividad supone ilicitud y, por ende, no puede denominarse la modalidad Claims made ni lo uno ni lo otro.

4. Desconoce el precedente de la CSJ, del Consejo de Estado y de la propia Superintendencia Financiera las cuales, como se verá más adelante, han reconocido la legalidad y aplicación de esta modalidad de cobertura en los seguros de responsabilidad civil. Ignora también que, ni en el Estatuto Orgánico del Sistema Financiero ni en la Circular Básica Jurídica, se ha indicado que cláusulas que pacten esta modalidad son abusivas.

5. El magistrado decide enfocarse únicamente en lo que considera abusivo, pero deja de lado las bondades de la modalidad de cobertura y así, desconoce los beneficios que trae la modalidad.

Por su parte, el Dr. Luis Armando TolosA, indicó en su salvamento de voto que:

"La inclusión de las cláusulas Claims made en un contrato de seguro de responsabilidad civil resulta abusiva e inconstitucional, violenta la buena fe negocial, transgrede 
los derechos del consumidor y quebranta el mandato constitucional, según el cual, es un fin esencial del Estado, asegurar la vigencia de un orden justo.

Se trata de cláusulas ineficaces que afectan los derechos de los usuarios y consumidores de seguros, porque erigen una valla de contención para la reclamación de indemnizaciones contra aseguradoras; pero además, son instrumentos de la propia autoprotección (en forma pleonástica por la naturaleza del contrato) del profesional del seguro y de las multinacionales del reaseguro..."

En términos generales, al igual que el magistrado Ariel Salazar, utiliza las mismas expresiones incluyendo frases comoviolaciónalabuena fenegocial einconstitucionalidad, desconociendo, en primer lugar, que esta modalidad debe ser pactada por las partes y que el artículo $4^{\circ}$ de la ley 389 de 1997 no ha sido declarado inexequible por la Corte Constitucional, haciendo que su consagración legal sea suficiente para entenderla perfectamente válida en el ordenamiento jurídico colombiano.

TolosA establece que la compañía aseguradora responderá únicamente por un hecho (made) ocurrido durante la vigencia de la póliza, y siempre que se formule el reclamo (claim) durante el período convenido en la misma póliza y durante su vigencia. En este punto incurre en el mismo error que el Dr. SALAZAR pues, por un lado, mezcla la modalidad Sunset con la de reclamación y, por el otro, olvida las demás posibilidades que ofrece la modalidad relacionada con las demás cláusulas que deben y pueden pactarse para que la modalidad otorgue una cobertura adecuada.

Establece que las víctimas resultan perjudicadas con esta modalidad de seguro, ya que "ellos no conocen el contenido, el alcance y los efectos del clausulado del contrato, el cual, por su naturaleza, es de adhesión para el tomador, por regla general; y ajeno del todo para terceros afectados. Esas reglas resultan inequitativas, irrazonables e inconstitucionales, máxime con la ignorancia de los consumidores de seguros sobre las categorías básicas del contrato correspondiente: infraseguro, prorrata, reticencia, riesgo relativo, coaseguro, pérdida por beneficio contingente, "Claims made", período de retroactividad, base de ocurrencia, cobertura, "descubrimiento de pérdidas durante la vigencia", "hechos ocurridos con anterioridad a su iniciación", etc.".

Parece sugerir el Dr. Tolosa que los consumidores no tienen la capacidad de comprender los efectos y pactos de un contrato que ellos mismos suscriben y parece, por ende, proponer que por ser la modalidad de reclamación un concepto altamente técnico y de una complejidad importante, las compañías aseguradoras no pueden utilizarlo. Llega a esta conclusión sin ninguna justificación técnica evidente y por lo mismo no es de recibo.

Menciona también que esas "cláusulas desconocen la existencia de siniestros tardíos, porque el daño en muchas hipótesis se manifiesta luego de largos períodos, traduciendo una ventaja lesiva contra terceros y asegurados; simplemente conducen a una exoneración de responsabilidad de las aseguradoras". Y más adelante explica que en muchas ocasiones el daño es tardío, poniendo los siguientes ejemplos: "daños al paciente en actos médicos, consumidores frente a productos defectuosos, daños estructurales de un edificio".

Lo anterior resulta particular pues precisamente en estos casos es que se justifica o se ve la utilidad de la modalidad de cobertura Claims made, ya que como el daño se 
puede manifestar tiempo después del hecho generador resulta óptimo contar con un seguro que permita cubrir las reclamaciones que se den justamente de forma tardía, cuando los perjuicios se hayan materializado.

El Dr. Tolosa, como el Dr. Ariel Salazar, reiteradamente indica que considera abusivas las "cláusulas Claims made" e indica que los jueces deben declararlas inválidas por afectar los derechos de los usuarios. Las mismas consideraciones sobre la abusividad de la modalidad, indicadas en el apartado correspondiente al Dr. Salazar aplican para estas afirmaciones del magistrado Tolosa.

Pero incurre en los siguientes errores:

1. Indica que pueden ser impuestas, lo cual no es cierto pues la norma es clara en indicar que esta modalidad puede ser pactada por las partes.

2. Establece que la Sala ha debido proceder a casar la sentencia recurrida, aplicando la excepción de inconstitucionalidad y de inconvencionalidad frente a las anunciadas cláusulas Claims made, omitiendo, de nuevo, que la Corte Constitucional no ha declarado la inexequibilidad de la norma, desconociendo la necesidad y utilidad de la modalidad y olvidando la legalidad de la disposición.

De acuerdo con lo expuesto en los párrafos anteriores puede concluirse que, si bien los magistrados tuvieron fuertes opiniones en contra de la modalidad de cobertura, su producción argumentativa no contempla la totalidad de las características de la modalidad, no tiene en cuenta el origen de esta y olvidan aspectos jurídicos básicos del derecho de seguros como la prescripción, los elementos del contrato de seguros y la protección al consumidor.

A pesar de lo anterior, llama la atención un asunto importante: en fallo posterior (03/12/2019, M.P. Luis Alonso Rico Puerta, SC5217-2019, Exp. 11001310301520080010201 ) ambos magistrados pudieron replicar tales argumentos pues se discutía el caso de la póliza de Errores y Omisiones que había tomado la Cámara de Comercio de Bogotá, la cual operaba modalidad Claims made y cuyo litigio versó precisamente sobre su forma de operar. Pero ninguno de los magistrados salvó su voto ni se pronunció al respecto de tal modalidad, estando de acuerdo con lo resuelto por el ponente y con sus argumentos sobre la modalidad Claims made, que fueron dirigidos a reconocer la legalidad, aplicación y operatividad de este tipo de cobertura temporal, lo cual nos lleva a preguntarnos qué pudo haber sucedido con sus polémicas intervenciones del 2017, acabadas de describir. ¿Cambiaron acaso de opinión? ¿Su silencio tendría algo que ver con el hecho de que el mercado reasegurador se estaba retirando del país, derivado de la inseguridad jurídica del 2019 que se tenía en los ramos especiales que utilizan tal modalidad de cobertura como Servidores Públicos, Directores y Administradores y Responsabilidad Profesional?

\section{POSTURA DEL CONSEJO DE ESTADO}

El Consejo de Estado (en adelante CE), aunque se ha pronunciado sobre las modalidades de cobertura temporal por reclamación Claims made en los casos de seguros sobre 
los que ha fallado, no lo ha hecho con tanta frecuencia como la Corte Suprema de Justicia; sin embargo, sí ha tenido la oportunidad de analizar su aplicación, legalidad y funcionamiento sobre todo en fallos de tutela en temas de responsabilidad civil médica de Empresas Sociales del Estado dedicadas a la prestación de servicios de salud, cuya actividad se encontraba amparada con seguros cuya modalidad de cobertura es la que en este documento se estudia.

En dichos fallos el CE generalmente hace un corto recuento histórico sobre la consagración de estas cláusulas en el artículo 4º de la Ley 389 de 1997 y, en términos generales, reconoce su aplicación legal siempre que el contrato de seguro cumpla con el requisito mínimo de claridad que permita entender que esta es la modalidad de cobertura consagrada. Teniendo en cuenta esta situación, ha fallado en consideración a la cláusula reconociendo los efectos temporales de la modalidad por reclamación o Claims made argumentando que la ley que la consagró se encuentra vigente.

A continuación, entonces, se hace un recuento de las sentencias en las cuales se evidencia más claramente este reconocimiento, anotando los aspectos relevantes de cada una de ellas sobre esta modalidad de cobertura.

Para empezar, se hace necesario mencionar la sentencia de la magistrada Stella Jeannette Carvajal Basto (28/11/2018, Exp. 11001031500020180229000) pues en esta se aclara que el origen de las cláusulas de modalidad de cobertura Claims made tiene una justificación en el equilibrio para las partes del contrato, no solo para las aseguradoras, sino también para los consumidores financieros al indicar que:

"En torno a las cláusulas "Claims made", la Sala de Casación Laboral de Corte Suprema de Justicia ha establecido que las mismas fueron admitidas en el ordenamiento jurídico en aras de lograr un equilibrio entre las necesidades de cobertura para los asegurados y una prima competitiva a través de los bajos costos para los tomadores, permitiendo pactar en el contrato de seguro, que la aseguradora únicamente pague la respectiva indemnización en los eventos en los que la reclamación es realizada durante la vigencia de la póliza" (2018).

Tienen en común casi todas las sentencias proferidas por este órgano que han versado sobre el tema, que reconocen la modalidad siempre que se pacte en seguros de responsabilidad civil, aclaración que realiza el magistrado Jorge Octavio Ramírez en fallo de 12 de febrero de 2019 (Exp. 11001031500020180002701 (AC)), al indicar que este tipo de modalidad sólo es aplicable a los contratos de seguro de responsabilidad civil y que la modalidad de cobertura "descubrimiento" consagrada en la misma ley 389 de 1997 es exclusiva para los seguros de manejo. Adicional a esto, transcribe la norma, la encuentra válida, y concluye que es primordial la claridad en este tipo de cláusulas con el fin de garantizar su correcta aplicación.

En fallo de tutela del 29 de mayo de 2014 (M.P. Gustavo Eduardo Gómez Aranguren, Exp. 11001031500020140062400), además de hacer un recuento histórico de este tipo de pactos y su consagración legal, se cita al Dr. Juan Manuel Diaz-Granados para aclarar de manera contundente que lo que hace este tipo de pactos no es modificar el régimen de responsabilidad de ninguna forma, y tampoco los términos de prescripción indicados en el Código de Comercio, pues esta figura es del tenor exclusivo del contrato de seguros. (2014) 
El magistrado Gómez Aranguren incluye en esta sentencia una explicación sobre cada uno de los posibles tipos de modalidad que pueden surgir teniendo en cuenta la redacción del plurimencionado artículo $4^{\circ}$, indicando lo siguiente:

"A raíz de lo dispuesto en el citado artículo, se han desarrollado una serie de cláusulas que delimitan temporalmente el riesgo en el seguro de responsabilidad civil, entre las que podemos mencionar el Claims made puro, con período de retroactividad, con período adicional, entre otros. Pero es posible que las partes convengan mezclas alternativas, como una cláusula de reclamación con una modalidad especial o con una de ocurrencia.

(...) En la modalidad de Claims made puro (reclamación pura), se brinda cobertura por hechos ocurridos en vigencia del seguro y que, a su vez, sean reclamados durante dicha vigencia, es decir, tanto el hecho como la reclamación deben tener lugar en vigencia de la póliza.

(...) En la modalidad de Claims made con período adicional (reclamación con período adicional), se podrá reclamar dentro de un período adicional a la expiración de la vigencia del seguro que, conforme el inciso $2^{\circ}$ del artículo $4^{\circ}$, en ningún caso podrá ser inferior a dos (2) años, con la condición que el hecho haya tenido ocurrencia dentro de la vigencia inicial".

A pesar de evidenciar que el CE entiende y aplica las cláusulas Claims made en los casos relacionados con contratos de seguro, es importante mencionar que, en algunos casos, teniendo en cuenta la narración de los antecedentes fácticos de los fallos revisados, se evidenció que tal vez los tribunales y los jueces de primera instancia no tienen tanta claridad frente a estas cláusulas.

Por ejemplo, en sentencia del 16 de agosto de 2018 (M.P. Rocío Araújo Oñate. Exp. 11001031500020170247900(AC)) no discute de ninguna forma la validez de estas cláusulas pues las encuentra naturalmente aplicables, pero teniendo en cuenta los argumentos sobre los cuales fundamentó el Tribunal su decisión aclara que este "no analizó la excepción planteada por La Previsora S.A., con base en el artículo 4 de la Ley 389 de 1997, que rige la modalidad de contrato de seguro que sirvió de fundamento para el llamamiento en garantía efectuado por el hospital demandado. Es decir, no analizó las implicaciones de esa disposición frente al caso concreto y, en su lugar, se remitió a las normas que regulan la prescripción de los derechos que surgen del contrato de seguro".

Aunado a lo anterior se encontró dentro de los antecedentes de la sentencia del 2014 mencionada del Magistrado Gómez Aranguren, que el Tribunal confundió el pacto de modalidad de cobertura Claims made con la prescripción y la ocurrencia de los hechos dañosos al indicar que:

“(...) en lo que se refiere a la declaración del hecho por fuera de la vigencia de la póliza, se tiene que la misma cubre los riesgos derivados de lo allí pactado dentro del término por ella señalado, también lo es que si se demuestra que el hecho ocurrió en vigencia de aquella, no importa si el conocimiento fuese posterior al vencimiento de la póliza, y que el mismo debe hacerse dentro de los dos años a la de tener conocimiento del hecho (...)".

Lo anterior llevó al magistrado a aclarar las modalidades de cobertura indicados en el artículo $4^{\circ}$ de la ley 389 de 1997 y su adecuada aplicación. 
Por otro lado llama la atención lo declarado por la magistrada Sandra Lisset Ibarra Vélez en la sentencia de tutela de enero de 2018 (12/03/2018, Exp. $11001031500020180002700(\mathrm{AC}))$, pues aunque es coherente con los planteamientos del CE en lo que se refiere a la validez, legalidad y aplicación de las cláusulas que pactan la modalidad de cobertura por reclamación o Claims made, indicó que siempre que se pacte el período adicional de notificaciones, se está frente a una modalidad Sunset.

Determinar si la modalidad de cobertura de una póliza es Claims made puro o Sunset, es un análisis que dependerá de la redacción de las cláusulas que se hayan pactado en el contrato de seguro; sin embargo, desde un análisis técnico, no siempre será posible llegar a esta conclusión, pues lo que determina qué tipo de modalidad está cubriendo el riesgo es la limitación para la ocurrencia y la reclamación del siniestro y el conjunto de las demás cláusulas del contrato de seguro, tales como el aviso de circunstancia y la retroactividad para cubrir hechos ocurridos con anterioridad al inicio de la póliza y no sólo el pacto de un período adicional de notificaciones.

En conclusión, a pesar de que no ha sido demasiado el desarrollo del CE sobre la modalidad de cobertura por reclamación o Claims made, este órgano de cierre ha llevado los fallos sobre esta materia a una aplicación natural de este tipo de modalidad incluyendo la aplicación de sus diversas formas.

No se evidencia en las sentencias estudiadas que el CE haya indagado nada más allá en razón de su consagración legal, aunque sí es claro que las considera beneficiosas para ambas partes, que entiende su forma de operar y falla en consecuencia, estando de acuerdo con lo planteado por la ley, la doctrina y los desarrollos de la propia CSJ, los cuales son los fundamentos técnicos de algunas de las sentencias del CE.

\section{POSTURA DE LA SUPERINTENDENCIA FINANCIERA DE COLOMBIA}

La Superintendencia Financiera de Colombia (en adelante SFC), como parte de sus funciones, gracias al artículo 28 del Código de Procedimiento Administrativo y de lo Contencioso Administrativo (en adelante CPACA), debe proferir los conceptos de carácter general y abstracto a que haya lugar como consecuencia de las consultas que se sean formuladas sobre las materias de su competencia.

Por esta razón es que frente a la modalidad de cobertura por reclamación o Claims made la SFC también se ha pronunciado a través de conceptos que, a pesar de ser pocos y de no ser estrictamente vinculantes, son importantes para entender cuál es la postura de esta entidad frente a la modalidad en discusión.

En el 2002 (Concepto 2002001008-2 del 24 de mayo de 2002), la SFC confirmó que la ley 389 de 1997 consagró la posibilidad de limitar la cobertura en el seguro de responsabilidad civil a través de las cláusulas Claims made. Más adelante, haciendo referencia al inciso segundo del artículo $4^{\circ}$ de esta Ley, estableció que pactar la modalidad allí consagrada correspondía al ejercicio de la autonomía de la voluntad de las partes, lo que excluye la posibilidad de que en ausencia de estipulación la norma 
resulte aplicable pues esta tiene carácter dispositivo y no supletivo de la voluntad de las partes.

Agrega, además, que la voluntad solo estará limitada para la modalidad Sunset en cuanto a la imposibilidad de pactar un término menor a los dos años previstos en la norma para presentar la reclamación lo que implica, a su vez, que es posible pactar un período de tiempo superior.

Años más tarde, en el 2016 (Concepto 2016118318-001 del 29 de noviembre de 2016) desarrolló algunos aspectos de la modalidad mencionada, en los siguientes términos:

"En esta modalidad de seguro, la cobertura asegurativa se encuentra vinculada a la reclamación formulada por el damnificado al asegurado o al asegurador dentro de la vigencia de la póliza, independientemente de que el hecho que las origina haya ocurrido dentro de la vigencia del contrato de seguro o antes de su perfeccionamiento".

De lo anterior se deberesaltar que, en nuestro concepto, la SFC incurre en una imprecisión técnica frente a esta modalidad al afirmar que bajo ella se cubren reclamaciones que se hayan originado en hechos que ocurren antes del perfeccionamiento del contrato de seguro, pues aunque esto puede ser una posibilidad si se otorgan fechas de retroactividad o se pacta expresamente, también puede estar excluido con la conocida cláusula de no cubrimiento de hechos ocurridos antes de iniciar vigencia y que fueran conocidos por el asegurado. Esto, como se dijo, dependerá de la forma en que se haya pactado en el contrato de seguro.

Lo que sí es cierto es que las nuevas modalidades traídas por el artículo $4^{\circ}$ de la mencionada ley pueden ser utilizadas por las compañías de seguros en función de la clase de riesgos cubiertos y que entre las partes del contrato de seguro podrán elegir la modalidad de cobertura. Por este motivo, la SFC (2016) se tomó el trabajo de explicar cada una de estas posibilidades, como se ve a continuación:

"1.1 Sistema tradicional o por ocurrencia.

Se amparan los daños ocasionados por siniestros ocurridos dentro de la vigencia de la póliza, sin tener en cuenta que la reclamación se efectúe después de la fecha de vencimiento del contrato, quedando excluidos de la cobertura los daños causados por siniestros acaecidos fuera de la vigencia de la póliza.

\subsection{Reclamación pura.}

Modalidad que permite el primer inciso del artículo 4 de la Ley 389 cuando afirma que "en el seguro de responsabilidad la cobertura podrá circunscribirse (...) a las reclamaciones formuladas por el damnificado al asegurado o a la compañía durante su vigencia, (...) así se trate de hechos ocurridos con anterioridad a su iniciación". En este caso la compañía de seguros está obligada a indemnizar sólo en el evento en que la reclamación del tercero damnificado se produzca dentro de la vigencia de la póliza, así se trate de hechos ocurridos antes del perfeccionamiento del contrato, siempre y cuando la reclamación por el tercero afectado se produzca dentro de la vigencia del contrato.

1.3 Reclamación especial

Teniendo en cuenta lo previsto en el inciso segundo de la norma en comento, en las pólizas de responsabilidad civil se podrá combinar el sistema de ocurrencia con el de 
reclamación, en donde se parte de la premisa de que los daños cubiertos son los que "acaezcan durante la vigencia del seguro", ligado a que "la reclamación del damnificado al asegurado o al asegurador se efectúe dentro del término estipulado en el contrato, el cual no será inferior a dos años"."

De acuerdo con lo anterior, se puede inferir que la SFC habla en el numeral 1.2. de la modalidad de reclamación o Claims made; mientras que en el numeral 1.3. se refiere a la modalidad Sunset, explicada en capítulos previos.

Finalmente, en 2018 (Concepto 2018039859-001-000 del 27 de abril de 2018) la entidad confirmó lo dicho en conceptos anteriores y agregó una línea importante sobre la legalidad de las pólizas de responsabilidad civil bajo la modalidad Claims made. Indicó que "las partes pueden usar cualquier modalidad de cobertura, ya sea por reclamación o por ocurrencia, o su combinación, desde la entrada en vigencia de la Ley 389 , que esta ley estaba vigente aún y que aquella posibilidad otorgada no puede constituirse una cláusula o práctica abusiva frente al asegurado".

Esto tiene unas implicaciones importantes porque, la SFC es la autoridad que inspecciona, controla y vigila a las compañías aseguradoras y a partir de sus conceptos técnicos ha establecido, confirmado y ratificado que la modalidad de cobertura por reclamación o Claims made es legal, perfectamente aplicable y en su más reciente pronunciamiento sobre el tema, que no es una cláusula abusiva el mero hecho de pactarla.

Finalmente, es importante mencionar que si bien la SFC tiene facultades jurisdiccionales, la modalidad de cobertura Claims made no ha sido objeto de pronunciamiento en ejercicio de las mismas.

\section{APLICACIONES DE LA MODALIDAD DE COBERTURA POR RECLAMACIÓN O CLAIMS MADE POR LA CONTRALORÍA GENERAL DE LA REPÚBLICA}

Teniendo en cuenta que la modalidad reclamación, como se ha visto, puede ser pactada únicamente en los seguros de responsabilidad civil, se hace importante resaltar la gestión de la Contraloría General de la República (en adelante CGR) teniendo en cuenta sus funciones de control fiscal y el impacto que han tenido sus interpretaciones sobre las cláusulas en los seguros contratados por las entidades que son sujetos de este tipo de control, como los de responsabilidad civil de servidores públicos o responsabilidad civil de directores y administradores.

Para ello, se resumirán a continuación algunos temas relacionados con las funciones de la CGR, la responsabilidad fiscal y los procesos para determinarla y la posibilidad de vincular a compañías aseguradoras a estos, para luego entrar en materia sobre la modalidad de cobertura por reclamación o Claims Made.

La Constitución Política de Colombia a partir del articulo 267 contiene la definición, asignación de tareas, trámites y alcance de las funciones de la CGR, dentro de los 
cuales está realizar el control fiscal a la administración pública y también a los particulares o entidades privadas que administren de alguna forma recursos públicos.

Hablando propiamente de la responsabilidad fiscal, el artículo $4^{\circ}$ de la ley 610 , que establece su trámite, indica que su objeto es el resarcimiento de los daños ocasionados al patrimonio público como consecuencia de la conducta dolosa o gravemente culposa de quienes realizan gestión fiscal, o de servidores públicos o particulares que participen, concurran, incidan o contribuyan directa o indirectamente en la producción de los mismos, mediante el pago de una indemnización pecuniaria que compense el perjuicio sufrido por la respectiva entidad estatal.

Lo que es importante de esta declaración es que la conducta que genere la responsabilidad puede ser dada por culpa grave -no sólo por dolo-, y que el responsable fiscal puede tener una participación indirecta en la causación del daño y aun así seguir siendo responsable.

Como asunto relevante para el análisis de las cláusulas Claims Made y de la interpretación que la Contraloría ha dado a estas, es necesario traer a colación el artículo 44 de la ley 610 el cual establece:

"Cuando el presunto responsable, o el bien o contrato sobre el cual recaiga el objeto del proceso, se encuentren amparados por una póliza, se vinculará al proceso a la compañía de seguros, en calidad de tercero civilmente responsable, en cuya virtud tendrá los mismos derechos y facultades del principal implicado.

La vinculación se surtirá mediante la comunicación del auto de apertura del proceso al representante legal o al apoderado designado por éste, con la indicación del motivo de procedencia de aquella".

Esto implica que al proceso de responsabilidad fiscal (en adelante PRF) se podrán vincular como garantes las pólizas que amparen de alguna forma la responsabilidad de los presuntos responsables fiscales.

La Corte Constitucional tuvo la oportunidad de analizar la exequibilidad de este artículo en sentencia C-648 del 2002 del Magistrado Jaime Córdoba Triviño en la cual aclara que:

"La vinculación del asegurador establecida en la norma acusada, además del interés general y de la finalidad social del Estado que representa, constituye una medida razonable, en ejercicio del amplio margen de configuración legislativa garantizado en estas materias por el artículo 150 de la Carta Política. Atiende los principios de economía procesal y de la función administrativa a que aluden los artículos 29 y 209 de la Constitución. Además, evita un juicio adicional para hacer efectivo el pago de la indemnización luego de la culminación del proceso de responsabilidad fiscal, con lo cual se logra, en atención de los principios que rigen la función administrativa, el resarcimiento oportuno del daño causado al patrimonio público. Así, desde la perspectiva del reparo de constitucionalidad formulado, no hay vulneración de las normas invocadas por los demandantes".

Adicionalmente, el Consejo de Estado (22/02/2018, M.P.: Alberto Yepes Barreiro, Exp. 08001233100020100061201), dentro de un proceso de nulidad y restablecimiento del derecho iniciado por una compañía de seguros, reitera lo indicado por la Corte 
Constitucional en la mencionada sentencia y aclara que la vinculación de las aseguradoras no se hace en calidad de responsables fiscales sino como terceros civilmente responsables, lo cual es importante pues aunque hacen parte del proceso, su responsabilidad no está comprometida en caso de fallo en contra y por lo mismo no son objeto de las consecuencias negativas por no pago que consagran las leyes relacionadas con el proceso y la responsabilidad fiscal. Indica además, que lo que se pretende con la vinculación de las compañías de seguros a los PRF es simplemente hacer efectivas las obligaciones adquiridas a través del contrato de seguros y es por esto que su responsabilidad se limita al riesgo amparado por el seguro. (2018)

Al respecto, indicó el doctor Juan Manuel Diaz-Granados en su artículo La Responsabilidad Fiscal y su incidencia en los seguros (2015) que las compañías de seguros no son gestores fiscales dado que no son administradores de recursos públicos y que su papel se limita a asumir determinados riesgos que pueden tener relación con eventuales detrimentos patrimoniales de entidades públicas. Establece que su obligación no nace de la ley fiscal sino del contrato de seguro y que esta se encuentra delimitada por dicho contrato. Más adelante, centra su análisis en las partes del contrato de seguros y cómo estas se evidencian en los PRF para concluir que "la vinculación de la aseguradora se produce directamente por decisión de las Contralorías, quienes no ostentan la calidad de asegurados (no sufren el eventual detrimento al patrimonio público). Las entidades públicas que son afectadas por dichos detrimentos no son parte, ni se involucran en el proceso de responsabilidad fiscal" 34 .

Teniendo en cuenta los antecedentes mencionados se hace necesario ahora analizar algunos PRF de conocimiento de la CGR que han involucrado Aseguradoras en calidad de terceros civilmente responsables, con el fin de entender cuál es la posición y su aproximación a las cláusulas Claims Made pues, como se mencionó previamente, la posición asumida por este órgano ha generado inseguridad jurídica e impactos en la oferta del mercado asegurador y reasegurador colombiano.

\section{PRF 6-007/11 (20/03/2012) sobre la Licorera del Valle (2012)}

Los hechos que dieron lugar a este PRF están relacionados con el contrato de distribución 20080035 y el plan de marketing desarrollado entre el año 2008 y el año 2011, por medio del cual se entregó mercancía a un proveedor específico para ejercer actividades de promoción de los productos. Consideró la CGR que el mencionado plan desbordó los criterios de razonabilidad, a pesar de que el resultado de este fue favorable ya que la entidad tuvo utilidades luego de varios años de pérdidas consecutivas, y por lo tanto vincula al proceso a varios funcionarios y a la compañía de seguros como tercero civilmente responsable por los seguros de Responsabilidad de Servidores Públicos. La CGR concluye que el detrimento patrimonial por ese concepto asciende a la suma de COP \$36,529,597,280.

\footnotetext{
34 Díaz-Granados, Juan Manuel. (2015). La Responsabilidad Fiscal y su incidencia en los seguros. Derecho de seguros y reaseguros, Liber Amicorum en homenaje al profesor Arturo Diaz Bravo. Colección de estudios, Pontificia Universidad Javeriana, p. 138.
} 
El auto de apertura se dio el 7 de abril de 2011 y teniendo en cuenta que las pólizas contratadas por la entidad para amparar la responsabilidad de los servidores públicos son de modalidad de cobertura Claims Made, la póliza vigente para este momento era la llamada a ser vinculada; sin embargo la CGR vinculó al proceso cuatro vigencias independientes, las cuales estaban vigentes desde la celebración del contrato antes mencionado. La compañía de seguros solicitó la desvinculación de aquéllas diferentes a la del 2011, teniendo en cuenta la modalidad de cobertura contratada.

En febrero de 2012 la CGR emite fallo con responsabilidad fiscal en el cual no hace ningún análisis sobre la modalidad de cobertura y confirma que deben ser todas las vigencias las vinculadas al fallo para responder por la pérdida fiscal y aunque fue apelado, los argumentos de la compañía aseguradora encaminados a indicar que la modalidad Claims Made debía ser respetada y de esta forma afectar sólo la póliza vigente al momento del auto de apertura, no fueron tenidos en cuenta. Se confirmó el fallo indicando que no era viable a la luz del proceso de responsabilidad fiscal aceptar la tesis planteada por la defensa de las aseguradoras; teniendo en cuenta que el fin que tiene el Estado con los PRF es la recomposición del patrimonio público, y por lo tanto confirma la condena al pago del hallazgo fiscal a todas las vigencias mencionadas en el auto de apertura y posterior imputación de responsabilidad fiscal.

Llama la atención que, en este fallo, la CGR centra su análisis en los términos de prescripción en una aparente confusión con la modalidad de cobertura y el momento de reclamación para indicar que finalmente, todas las vigencias son llamadas a responder afectando todos los límites asegurados.

\section{PRF Instituto Colombiano de Bienestar Familiar (ICBF)}

La Contraloría inició este PRF en contra de algunos funcionarios del ICBF con el fin de recomponer el patrimonio de esta entidad teniendo en cuenta que como producto de una auditoría se encontró que había pagos realizados a ALMA MATER sin encontrar una contraprestación de servicios, en el marco de convenios celebrados por las partes entre el 2008 y el 2010. La CGR concluye que el detrimento patrimonial por ese concepto asciende a la suma de $\$ 4,694,275,217$.

Teniendo en cuenta que el ICBF contrata pólizas de responsabilidad para sus servidores públicos que amparan el patrimonio de estos en caso de encontrarse responsables por actos incorrectos en el ejercicio de sus funciones, decide la CGR vincular las pólizas que estuvieron vigentes durante el período de duración de los convenios, período en el cual se realizaron los pagos sin recibir una contraprestación respectiva, esto es tres pólizas diferentes, con límites asegurados independientes y, más importante, con modalidad de cobertura Claims Made contratadas con la Previsora S.A. Compañía de Seguros.

Mediante auto 203 de 2017 la CGR profirió fallo con responsabilidad fiscal, frente al cual la aseguradora renunció al recurso de apelación; sin embargo, teniendo en cuenta los argumentos esgrimidos por la CGR en el fallo, solicitó la revocatoria del mismo alegando entre otros argumentos que la CGR debía reconocer la aplicación de las cláusulas Claims Made y condenar sólo a una, tal como lo había hecho en circunstancias anteriores. Consideró la aseguradora que la CGR había vulnerado las 
normas procesales al no indicar claramente el sustento de la vinculación de las pólizas pues se limitó a mencionarlas y, de esta forma, se dificultó la defensa de esta y aclaró además que las cláusulas Claims Made son legales y de ninguna forma abusivas.

La solicitud de revocatoria no fue concedida por la CGR alegando frente a los argumentos presentados por la aseguradora que el despacho sí analizó que los amparos de las pólizas condenadas guardaran relación con los hechos generadores del detrimento patrimonial, situación que se informó desde el auto de vinculación, lo que permitió a la aseguradora adelantar su adecuada defensa.

Frente al argumento de las cláusulas Claims Made, indica la CGR que esa modalidad es una cláusula abusiva impuesta por la compañía de seguros en desequilibrio de la parte asegurada, que va en contravía del fortalecimiento de los derechos indemnizatorios de las víctimas a obtener el pago de las aseguradoras y, adicional, aclara que este no es un elemento esencial del contrato como sí lo es el pago cuando se materializa el riesgo asegurado, por lo que concluye que sólo se respetan las modalidades de cobertura cuando estas no sean abusivas y contrarias al interés público y que en caso contrario se debe entender que la modalidad de cobertura aplicable es la de ocurrencia y así se deben interpretar las condiciones del seguro.

En este fallo se evidencia que la CGR encuentra que la modalidad de cobertura sólo beneficia a la aseguradora y por lo mismo debe entenderse como no pactada y de esta manera proteger a cabalidad el interés general.

3. PRF 038/2012 (09/10/2017) sobre la Unidad Administrativa Especial de Servicio Públicos -UAESP-/Esquema de Aseo.

Aunque inicialmente eran varios PRF relacionados con este tema, finalmente sólo uno tuvo fallo negativo y sobre ese exclusivamente se enfocará el análisis.

Este PRF tuvo origen en una denuncia pública realizada por senadores de la República sobre el manejo del esquema de aseo en la ciudad de Bogotá. Luego de una auditoría por parte de la CGR, concluye esta que es necesaria la apertura del proceso teniendo en cuenta los siguientes hechos conocidos:

En Bogotá la recolección de la basura está a cargo de una Unidad Administrativa Especial de Servicios Públicos (UAESP), esta entidad cuenta con la "Bolsa General del Esquema de Aseo" en la cual se tienen los recursos que se reciben por la prestación de los servicios públicos; uno de estos ingresos es la tarifa que se cobra en las cuentas de servicios públicos, tarifa que tiene una destinación específica: ser invertidos en la prestación del servicio de recolección de basuras.

En el año 2002 la UAESP convocó una licitación para contratar la prestación del servicio de recolección de basuras y fue adjudicada a los operadores LIME, ATESA, ASEO CAPITAL Y CIUDAD LIMPIA, estos operadores usarían los recursos tarifarios bajo la condición de constituir una fiducia para el recaudo, administración, liquidación y pago de los ítems relacionados con la prestación del servicio de recolección de basuras. La fiducia se constituyó con Fiduciaria Bancolombia y desde su constitución hasta el año 2011 no hubo inconvenientes frente a su funcionamiento. 
En el 2012, el Senado, haciendo uso de sus facultades, pide a la CGR hacer una revisión de los contratos que manejan la bolsa general del esquema de aseo. Por ende, la Contraloría en el 2012 inició dos investigaciones fiscales al respecto de estos contratos, el PRF 009/12 y el PRF 038/12, posteriormente desagregó el 038/12 en dos procesos más, el 003/14 y el 004/14, y finalmente, en el 2015 teniendo en cuenta la similitud de los hechos entre el proceso 038/12 y el 009/12 la Contraloría decidió unificarlos.

La CGR imputó responsabilidad a los concesionarios, a los funcionarios de la UAESP que manejaban la Bolsa General del Esquema de Aseo y a las compañías aseguradoras que amparaban la responsabilidad de estos imputados. Por ejemplo, para amparar la responsabilidad de la Fiduciaria, la CGR vinculó como tercero civilmente responsable a la aseguradora de las pólizas de responsabilidad profesional vigentes entre el 2003 y el 2010, sin embargo, no vinculó a la póliza vigente al momento de dictar el auto de apertura.

El hallazgo fiscal se concretó para el PRF en COP \$47,425,968,533 y la CGR encontró responsables a los concesionarios y a la Fiduciaria, condenando a la compañía aseguradora al pago de la parte correspondiente a la Fiduciaria.

Frente a los argumentos presentados por la aseguradora buscando la adecuada vinculación al proceso se encuentra que la CGR no mencionó los fundamentos técnicos que llevaron a vincular a la compañía aseguradora, también indicó que no se puede imputar responsabilidad fiscal a un tercero civilmente responsable por el mero hecho de expedir una póliza, que la existencia de un contrato de seguros no se puede entender como que la aseguradora está destinada a amparar todos los hechos que ocurren universalmente y mencionó también la violación al derecho de defensa, ya que, al no haber fundamentos técnicos para su vinculación, se imposibilita la defensa.

Recordó la defensa de la aseguradora que cada que hay renovación de la póliza se da un nuevo contrato y por lo mismo no se pueden vincular todas las vigencias, esto implica que si se presenta un siniestro éste se ampara por la póliza vigente al momento de configurarse y no aplica la vinculación de múltiples contratos de seguro, pues no se cumplen los requisitos contractuales para que operen ya que la póliza era de modalidad Claims Made y la reclamación debía presentarse durante la vigencia de la póliza, situación que no ocurrió.

En el fallo de primera instancia emitido por la Contraloría no fue clara la condena contra la aseguradora y por lo mismo, se interpuso recurso de reposición y en subsidio apelación fundamentado en los argumentos presentados en la etapa de alegatos. Estos recursos fueron rechazados $\mathrm{y}$, por lo tanto, se confirmó el fallo respecto de los responsables fiscales y solamente se aclaró el fallo para indicar que la aseguradora de la Fiduciaria fue efectivamente condenada en su calidad de tercero civilmente responsable.

Vale la pena citar un aparte del auto por medio del cual se resuelve el grado de consulta y de apelación sobre el tema de interés de este documento. Indica la CGR que “... tampoco resulta aplicable a este proceso de responsabilidad fiscal el artículo 4 de la ley 389 de 1997, toda vez que esta hará nugatoria cualquier vinculación de este tipo de pólizas a este proceso, generando una merma injustificada en la reparación de los recursos públicos.” Y más adelante siguiendo la misma lógica declara que las 
disposiciones del Código de Comercio son inoponibles a los contratos de seguros estudiados en el proceso fiscal dado el carácter público de la norma fiscal.

Esta declaración resulta contraria a lo ya analizado por la Corte Constitucional, la CSJ y el CE y lo declarado en las normas relacionadas con la vinculación de los seguros que amparen la responsabilidad a los PRF, ya que se debe respetar el objeto de la cobertura y las condiciones del contrato al momento de la vinculación y no inaplicar normas con el fin de buscar una indemnización más completa y considerar que por tener este tipo de procesos un carácter especial se pueden desconocer las normas particulares que rigen los contratos de seguros.

4. PRF 2014-05388 (12/06/2019) sobre el Instituto de Desarrollo Urbano de Bogotá.

Los hechos que dieron lugar a este PRF se resumen en que la CGR encontró algunas irregularidades en la etapa precontractual de dos contratos de obra pública de 2007 en los que, mediante otrosíes, se acordó con contratistas la realización de modificaciones a los estudios y diseños de Transmilenio, sin haber finalizado el plazo para la entrega inicialmente convenida mediante contratos del 2005. Por lo tanto, inicia el PRF en contra de los funcionarios involucrados en esta negociación.

El detrimento patrimonial encontrado fue de COP $\$ 5,278,888,768$ el cual se origina por la entrega tardía o incompleta de los productos por parte de los diseñadores consultores de acuerdo con los contratos estudiados, por causa de las actualizaciones y modificaciones, que generaron que algunos productos entregados no se ajustaran a las condiciones reales del contrato, sumado a una mala planeación de los gestores públicos.

Para este proceso, el cual inició en 2014, la CGR vinculó como terceros civilmente responsables a dos compañías de seguros teniendo en cuenta las pólizas vigentes al momento de ocurrencia de los hechos, a saber, aseguradora 1 pólizas con vigencias entre el año 2004 y el 2007 y aseguradora 2 pólizas vigentes entre 2007 y 2011; como se ve ninguna vigente al momento de la apertura del PRF.

Es importante mencionar que en primera instancia se decretó el archivo del proceso, sin embargo, en grado de consulta se ordenó la reapertura de éste y es en grado de consulta que se adelanta el proceso y se da el fallo con responsabilidad fiscal.

Las aseguradoras en su defensa le indicaron a la CGR una serie de argumentos frente a las vinculaciones, de los cuales resaltaremos los más relevantes, a saber: se recordó a la CGR la ausencia de cobertura de las pólizas vinculadas por ser modalidad Claims Made, teniendo en cuenta el artículo $4^{\circ}$ de la Ley 389, antes citado y mencionado en este documento y además se menciona como algo evidente que no hubo ninguna reclamación en las vigencias de la póliza relacionada con este tema. Adicionalmente, se indica que la ley 610 del 2000 no puede primar sobre la ley mercantil en materia del contrato de seguros.

A los argumentos presentados por las aseguradoras, fue contundente la CGR al indicar que la modalidad de cobertura Claims Made no es un elemento esencial en el contrato de seguros, argumento que previamente ya había sido esgrimido por este ente, y por 
lo tanto no le aplica a los PRF pues considera que se trata de una cláusula limitativa de responsabilidad que no atañe al interés asegurable ni al riesgo asegurable; y teniendo en cuenta que el control fiscal, para el momento del fallo, era posterior y selectivo, resulta imposible para la Contraloría hacer efectiva la reclamación en el tiempo indicado.

Pero adicionalmente, frente a las cláusulas Claims Made indica que con el pacto de estas sólo percibe réditos la aseguradora, la cual además es desproporcionada y genera un desequilibrio contractual en contra del asegurado y por lo mismo para los efectos del contrato debe resultar ineficaz por desconocer normas de orden público.

Frente a la aplicación preponderante de la Ley 610 sobre las normas mercantiles aclara la CGR que prevalece la primera, pues es la que le permite desarrollar la función constitucional. Finalmente aclara que como el principio del derecho declara que lo accesorio sigue la suerte de lo principal, en este caso como la vinculación de las aseguradoras se hace en función de garante del responsable fiscal, que sería el sujeto principal de la relación en el PRF, se debe aplicar la norma específica que regula el procedimiento y no la sustancial que regula la relación entre las partes del contrato.

Atendiendo a estas declaraciones las aseguradoras solicitaron la revocatoria directa del fallo teniendo en cuenta su contenido contrario a las normas mercantiles aplicables a los contratos de seguro. En este recurso además las aseguradoras incluyen dentro de sus argumentos dos aspectos nuevos que resultan relevantes: primero, allegan al proceso copia del seguro de responsabilidad civil de servidores públicos vigente al momento de la apertura del PRF y alegan que es este el llamado a responder como garante de los funcionarios del IDU y declaran, además, que este tipo de decisiones en las que se condena a las compañías de seguros acumulando vigencias y valores asegurados y se inaplica la modalidad de cobertura Claims Made "genera importantes restricciones de disponibilidad de respaldo en el mercado internacional de reaseguros en relación con las pólizas de responsabilidad civil que protejan a los servidores públicos, que consecuencialmente, genera serias limitaciones para la oferta de pólizas de seguros para los servidores públicos", y además que este tipo de decisiones "mina la credibilidad del ordenamiento jurídico del país y compromete seriamente la seguridad jurídica...".

Aunque la CGR efectivamente revoca el fallo frente a las compañías aseguradoras y procede a declarar civilmente responsable a la aseguradora que tenía un seguro vigente al momento de la apertura del proceso, esto es, en el 2014, declarando que:

Dicha vinculación se dio teniendo en cuenta que, al sólo poder ejercer el control fiscal de manera posterior a la configuración del daño patrimonial, las condiciones de las pólizas afectadas llevarían a concluir que no ampararían el obrar de los funcionarios declarados fiscalmente responsables, haciendo inocuo el aseguramiento y dejándolo sin respaldo.

Lo que podría entenderse como una declaración de la CGR de que siempre que no encuentre un seguro vigente al momento de la vinculación, procederá a condenar a las pólizas vigentes durante la ocurrencia de los hechos, sin importar su tipo de modalidad de cobertura, para garantizar la reparación del patrimonio. 


\section{PRF 00329-2015 (29/08/2019) sobre la Industria Licorera de Caldas - ILC.}

El PRF contra funcionarios de la ILC, es uno de los fallos más recientes que ha tenido impacto nacional en el ámbito de los seguros por sus decisiones, el fundamento que da lugar a su apertura se concentra en ciertas irregularidades en unas exportaciones de licor en el año 2002, las cuales llevaron a la DIAN a imponer multas contra esta entidad. En el 2013 la ILC paga a la DIAN la suma de COP \$1,190,226,914, sin embargo, en el 2015 la CGR inicia un PRF en contra de los funcionarios de la entidad por considerar precipitado el pago de estas multas.

En este PRF se vincula a la compañía de seguros en virtud de la póliza cuya vigencia fue del 2001 al 2003, por ser la que estaba vigente al momento de realizar las exportaciones, la cual amparaba la Responsabilidad Civil de los Servidores Públicos. Es importante mencionar que la aseguradora no tenía pólizas vigentes que amparaban este riesgo al momento del auto de apertura del proceso.

Los argumentos expresados por la aseguradora vinculada buscando no ser condenada, son similares a los ya indicados para los demás procesos pues se centran especialmente en la aplicación de la modalidad de cobertura contratada, esto es modalidad Claims Made, lo que implicaba tenerse que vincular la póliza vigente al momento de la reclamación y no la vigente en el momento de la ocurrencia de los hechos y, adicionalmente, pues lo que se reclama es el pago de una multa, situación inasegurable a la luz de la normatividad aplicable a los contratos de seguros.

La CGR sin embargo, encuentra probado el detrimento patrimonial y por lo mismo procede a dictar fallo con responsabilidad fiscal, alegando frente a los argumentos de la aseguradora que la modalidad de cobertura Claims Made no es aplicable a este tipo de fallos, pues la responsabilidad contra los vinculados solo se declara en la decisión final y es en esta actuación en donde se indica definitivamente cómo ocurrieron los hechos que dieron lugar al detrimento patrimonial, quiénes efectivamente causaron el daño y por lo tanto están llamados a responder y finalmente se define el valor final del detrimento. Tampoco tienen aplicación, pues la CGR no hace parte del contrato de seguro, ni se entiende como asegurada o beneficiaria y por lo mismo no es dable entender el auto de apertura como la reclamación necesaria para determinar la ocurrencia del siniestro en los seguros con este tipo de modalidad de cobertura; recuerda la CGR el fallo es, en sí, una declaración de responsabilidad.

Esta decisión fue apelada, pero la CGR la confirmó en todas sus partes el 31 de enero de 2020, condenando a la aseguradora a pagar aun así no estuviera vigente la póliza al momento de iniciar la reclamación. En este punto, se hace necesario mencionar que el Contralor General de la República el 16 de marzo de 2020 emitió la Circular 005/20 dirigida a la Contraloría Delegada para la Responsabilidad Fiscal, Intervención Judicial y Cobro Coactivo, Unidad de Investigaciones Especiales contra la Corrupción, Unidad de Responsabilidad Fiscal, Direcciones de Investigaciones, Gerencias Departamentales Colegiadas en la cual expone una serie de aspectos a tener en cuenta al momento de vincular compañías de seguros dentro de los PRF, en la cual reconoce la legalidad de la modalidad de cobertura Claims Made y la correcta forma de analizar las vigencias de los contratos de seguro para su vinculación. 
Más adelante se analizará con mayor profundidad esta circular, sin embargo, se hace necesaria su mención teniendo en cuenta el desenlace final que tuvo el proceso que se estudia. Es preciso mencionar que en este documento el Contralor indica que "las obligaciones de la aseguradora tienen límites, entre otros, la suma asegurada, la vigencia, los amparos, las exclusiones, los deducibles, los siniestros, establecidos en el clausulado del contrato de seguros correspondiente", situación relevante pues reconoce que en las vinculaciones de las compañías aseguradoras a los PRF se deben respetar las condiciones negociadas en el contrato de seguros.

Posteriormente aclara que se debe tener en cuenta el hecho generador que da lugar al PRF y contrastarlo con los siniestros cubiertos por las pólizas que potencialmente se afectarán y "a partir de allí, analizar las condiciones generales y particulares del contrato de seguros, la base o modalidad (ocurrencia, descubrimiento, reclamación o Claims Made, etc.) de la cobertura del seguro que se pretende afectar y las demás condiciones del contrato, con miras a determinar tempranamente y con absoluta claridad cuál es la póliza llamada a responder (en virtud de las vigencias, el ramo de seguros, etc.)." Esta última declaración, podría considerarse la más importante de cara al tema de estudio pues, como se ha visto, es la primera vez que la CGR reconoce abiertamente que esta modalidad debe ser reconocida y analizada para garantizar la adecuada vinculación al PRF.

Se hace esta mención a la Circular 005, pues en el desarrollo del medio de control (posterior a la publicación de la mencionada Circular), el Comité de Conciliación de la Contraloría, le propuso a la compañía de seguros como fórmula conciliatoria revocar el fallo en lo relativo a su vinculación como garante en el PRF, al reconocer que la póliza fue contratada bajo la modalidad de cobertura Claims Made y a la fecha de apertura del proceso la póliza inicialmente vinculada no estaba vigente. Sobra decir que la compañía aseguradora aceptó esta fórmula de conciliación y por lo mismo fue desvinculada del PRF.

\section{PRF-2017-00309_UCC-PRF-005-2017 - Refinería de Cartagena S.A. - Reficar}

La CGR inició PRF en contra de algunos funcionarios de Reficar, miembros de junta directiva y otros contratistas con fundamento en las mayores inversiones en el proyecto que en concepto de este órgano no agregaron valor; adicionalmente se indica en la narración de los hechos que dan origen a este proceso, que se presentaron gastos que no estaban relacionados con el proceso de modernización de la refinería como mayores gastos en la contratación del personal, baja productividad de la mano de obra y "demoras en las actividades propias del proyecto causadas por acciones y omisiones, por parte de la junta directiva de Reficar, la administración de Reficar, contratista y supervisor del proyecto." 35

\footnotetext{
35 Tomado de: https://www.contraloria.gov.co/contraloria/sala-de-prensa/boletines-de-prensa/boletinesde-prensa-2021/-/asset_publisher/9IOzepbPkrRW/content/contraloria-profirio-fallo-con-responsabilidadfiscal-por-2-9-billones-de-pesos-en-el-caso-reficar-por-mayores-inversiones-que-no-le-agregaron-valor-a
} 
Se hace importante mencionar en este punto algunos antecedentes relacionados con el origen de ese proceso que son relevantes para analizar las decisiones tomadas por la CGR en el caso.

Sea lo primero indicar que, según las defensas presentadas por las aseguradoras vinculadas como terceros civilmente responsables, la primera fecha en la que los asegurados de las pólizas de Directores y Administradores (en adelante D\&O) tuvieron conocimiento de una eventual reclamación derivada de la ejecución del proyecto de modernización de la Refinería de Cartagena fue la indagación preliminar IUS-2012332368, iniciada el 30 de agosto de 2012 por la Procuraduría General de la Nación. Dicho reclamo fue notificado a la aseguradora cuya póliza de D\&O estaba vigente para el momento en que se conoció esta actuación, esto es, dentro de la vigencia 2012/13. Adicionalmente, la CGR vinculó a varias aseguradoras por las diferentes pólizas de D\&O que estuvieron vigentes a lo largo del proyecto, esto es, desde el 2011 hasta el 2018.

La defensa de las varias aseguradoras vinculadas consistió en reiterar a la CGR la importancia de reconocer la modalidad de cobertura Claims made en este tipo de seguros, la presencia de la cláusula de unidad de evento, de acuerdo con la cual se entenderán presentadas todas las reclamaciones derivadas de un mismo hecho en la vigencia en la que primero se tuvo conocimiento. Finalmente, alegan los apoderados que no es posible unificar vigencias de una misma póliza, pues a pesar de haberse renovado consecutivamente, cada vigencia es autónoma e independiente en cuanto a sus coberturas y condiciones.

Frente a estos argumentos, indica en el fallo la CGR que dará aplicación a la Circular 005, y por lo mismo considera que la compañía de seguros llamada a responder como tercero civilmente responsable por los hallazgos fiscales es aquella que había emitido la póliza que estaba vigente al momento de la notificación del PRF a las compañías aseguradoras, es decir la póliza vigente en 2017/18, ya que la notificación se dio el 27 de abril de 2018. Acepta la CGR que tratándose de una póliza de modalidad de cobertura Claims Made no es posible acumular valores asegurados de diferentes vigencias y es por esto por lo que se vincula al fallo la vigencia antes mencionada.

Aunque es bastante positivo que la CGR haya reconocido la aplicación de la modalidad de cobertura Claims Made es necesario llamar la atención de ciertos puntos relevantes que continúan afectando al mercado de seguros y reaseguros colombiano.

- Se menciona en el fallo que a los PRF no les son aplicables las exclusiones de culpa grave o dolo ya que son elementos esenciales para acreditar la responsabilidad fiscal de acuerdo a lo contenido en las normas que regulan la materia, frente a la culpa grave no representa una circunstancia demasiado gravosa pues el ordenamiento jurídico colombiano permite asegurar la culpa grave en seguros de responsabilidad civil, sin embargo asegurar el dolo va abiertamente en contra de los preceptos normativos del Código de Comercio.

- El fallo indica que no hay un momento específico para determinar la póliza a vincular, ya que considera que puede ser la notificación al asegurado o la vinculación de la compañía aseguradora; situación compleja y de alta insegu- 
ridad jurídica pues no indica los criterios para determinar si es uno u otro momento. Además, ignora el aviso que las compañías aseguradoras ya conocían los hechos que dieron origen al PRF y por consiguiente, el pacto contractual relacionado con la unidad de evento.

Como se evidencia con estos seis ejemplos de fallos de PRF, las decisiones que ha tomado la CGR son, de una forma u otra, contrarias a las normas vigentes del ordenamiento colombiano sobre el contrato de seguros, a la posición que han asumido las Altas Cortes e incluso la Superintendencia Financiera de Colombia.

Esta situación, como lo mencionó uno de los apoderados de aseguradoras en su defensa, no solo violenta el ordenamiento jurídico sino que también genera inseguridad jurídica respecto a las coberturas de los seguros y por lo mismo, generan una modificación la oferta, que el mercado de seguros y reaseguros está dispuesto a entregar.

Algunos de los PRF fallados por la Contraloría en el sentido antes indicado están siendo revisados por el Consejo de Estado, y aunque estas acciones aún no han sido decididas, serán determinantes para los futuros PRF ya que se le presenta la oportunidad a este órgano de cierre de pronunciarse de fondo sobre esta modalidad.

Aunque la Circular 005 de 2020 es un avance y hay evidencias de la voluntad de la CGR de aplicarla, será necesario esperar el desarrollo de todos los demás PRF que hoy en día vinculan varias vigencias del seguro, sin importar la modalidad de cobertura negociada.

\section{PROPUESTAS}

Como se ha evidenciado a lo largo de este documento, a pesar de la consagración legal de la modalidad de cobertura Claims made y de su vigencia innegable no hay uniformidad en la aceptación de estas cláusulas ni en la doctrina, ni en el concepto unánime de los magistrados de la Corte Suprema de Justicia y mucho menos de su aplicación por parte de la Contraloría.

Es por esto que se analizarán las propuestas realizadas por doctrinantes o instituciones del sector asegurador y del sector público con el fin de garantizar una adecuada interpretación

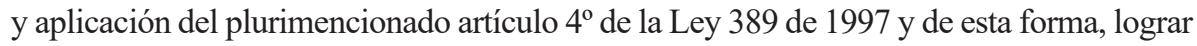
para las partes del contrato de seguros y reaseguros la seguridad jurídica necesaria para poder operar y para los consumidores financieros una adecuada cobertura.

La profesora Mónica Lucía Fernández Muñoz, (2002, pp. 234-235) dedica un aparte completo a proponer medidas que podrían solucionar estos efectos negativos. Frente al inconveniente planteado sobre los eventuales vacíos de cobertura derivados de la ocurrencia del hecho generador del daño en vigencia, pero no reclamado en vigencia de la póliza, se proponen dos soluciones que, aunque la autora no las encuentra convenientes por generar un desequilibrio en contra de las aseguradoras, vale la pena mencionarlas. La primera solución es constituir un fondo de garantías para garantizar a los asegurados la cobertura que pierden eventualmente, teniendo 
en cuenta el supuesto de hecho inicialmente planteado; este fondo se alimentaría con recargos en las primas. La segunda opción es que las compañías otorguen períodos de retroactividad ilimitados o suficientemente amplios para evitar vacíos de cobertura.

Otra propuesta está referida a la disminución de los términos de prescripción consagrados en el Código Civil; esta situación limita a la víctima, pero garantiza un poco de seguridad al asegurado y a la aseguradora, pues reduce la incertidumbre de la reclamación. En este mismo sentido se propone también la posibilidad de un acuerdo entre las partes en donde se amplíe el período para presentar las reclamaciones alineado con los términos de prescripción vigentes. Esta, aunque es una propuesta viable de cara a la autonomía de la voluntad, contradice el propósito de la modalidad de cobertura misma que es evitar siniestros de cola larga.

Teniendo en cuenta lo anterior se encuentra que, aunque la doctora FERNÁNDEZ en su artículo hace un análisis profundo sobre esta modalidad de cobertura y su impacto, las soluciones planteadas no resuelven el problema que presentan este tipo de cláusulas; sin embargo, encontramos en los demás doctrinantes y actores propuestas que solucionan de manera más contundente los problemas encontrados sobre esta modalidad de cobertura temporal.

Por ejemplo, Nicolás Uribe (2013, pp. 379-381) dedica un capítulo completo a este preciso análisis concentrándose en las ventajas y desventajas de esta modalidad, las cuales fueron ampliamente ilustradas al inicio de este documento, para finalmente concluir en cuál sería la forma adecuada de este pacto para evitar que sea considerada de alguna forma abusiva. Concluye Uribe en su libro que, aunque las críticas en gran medida sean acertadas e irrefutables, no puede satanizarse esta modalidad de cobertura ya que si es empleado de manera adecuada puede otorgar a las partes del contrato el fin buscado, es decir, evitar colas largas de cara a los siniestros y lograr una indemnización adecuada.

Este autor propone que para lograr un adecuado funcionamiento de la modalidad de cobertura Claims made, es necesario que coexistan varios parámetros mínimos con el fin de lograr que dicha modalidad funcione sin contratiempos y de forma razonable. El primer parámetro se refiere al período retroactivo, el cual se debe ampliar con cada renovación sucesiva. Así las cosas, para la primera vigencia contratada puede ser que no se pacte esta cláusula, es decir que no se cubran hechos ocurridos con anterioridad; sin embargo, a medida que se generen renovaciones consecutivas será necesario que la compañía otorgue cobertura retroactiva para los hechos ocurridos en vigencias pasadas, pero eventualmente reclamados, así cada renovación anual suma un año de retroactividad.

Otro elemento importante que trae Uribe en su análisis, podría entenderse más bien como una correcta aplicación de las normas del contrato de seguro de responsabilidad civil, pues aclara que de ninguna forma puede condicionarse la configuración material del siniestro a que el asegurado notifique esta situación a la aseguradora; sin embargo, por ejemplo el artículo 1131 del Código de Comercio establece claramente que los términos de prescripción empiezan a correr a partir de la reclamación de la víctima al asegurado; y aunque esta norma no habla particularmente de la modalidad de cobertura 
objeto de estudio, sí puede aplicarse como una analogía del momento de configuración del siniestro en los seguros con modalidad de cobertura por reclamación.

Agrega, además, la necesidad de incluir cláusulas que otorguen cobertura por reclamaciones recibidas en el futuro por hechos ocurridos durante la vigencia, es decir coberturas prospectivas, sobre todo si se trata de la última vigencia que el tomador contratará con la compañía de seguros; en el mercado se conoce esta cobertura como período adicional de notificaciones o reportes y generalmente viene acompañada del cobro de prima proporcional. Recomienda Uribe (2013, p. 381) que este precio esté pactado desde el inicio de vigencia para evitar discusiones sobre su cuantía.

Ahora bien, en cuanto al siniestro y su eventual materialización, recomienda que todos los condicionados generales de seguros con esta modalidad de cobertura, pacten claramente el curso que tendrán aquellas circunstancias conocidas en vigencia del seguro y reportadas debidamente a la aseguradora, frente a las cuales no se ha recibido ninguna reclamación, pero se tiene algún grado de certeza razonable sobre las reclamaciones futuras; y además considera que "estas reclamaciones estarán cubiertas por el seguro que estaba vigente cuando se tuvo conocimiento de dicha circunstancia y desde luego se dio aviso a la aseguradora sin que importe para el efecto la fecha en que se realice efectivamente la reclamación por parte de la víctima al asegurado o a su asegurador" 36 . Este parámetro es relevante pues en los condicionados generales de seguros con esta modalidad también es común encontrar la exclusión de circunstancias conocidas con anterioridad a la entrada en vigencia del seguro. Esta estipulación, aunque común, podría desvirtuar el propósito de la modalidad de cobertura que es disminuir los siniestros de cola larga, al tener circunstancias avisadas que potencialmente puedan generar siniestros en el futuro lo que implica, como mínimo, impactos en las reservas técnicas con la de siniestros incurridos, pero no reportados (IBNR por sus siglas en inglés).

Concluye Uribe que siempre que se respeten los cuatro parámetros mencionados este sistema de cobertura temporal podrá operar sin contratiempos de cara a la compañía de seguros que asume los riesgos y a las víctimas que eventualmente reclamarán los perjuicios causados por los asegurados.

Entrando ahora al gremio de las aseguradoras, se presentó una propuesta de circular externa a la SFC buscando que este órgano regule los seguros con modalidad de cobertura Claims made. En esta propuesta, la compañía aseguradora busca que se brinde claridad respecto de la modalidad mencionada no sólo para la correcta aplicación por parte de las compañías aseguradoras, sino también el correcto entendimiento de los consumidores financieros cuando son usuarios de seguros con esta modalidad, el cual cuenta con un recuento de los antecedentes nacional e internacionales que llevan a esta propuesta, la cual pretende adicionar un numeral a la Circular Básica Jurídica (en adelante $\mathrm{CBJ}$ ) existente.

\footnotetext{
36 Uribe Lozada, Nicolás (2013). El régimen general de responsabilidad de los administradores de sociedades y su aseguramiento. Pontificia Universidad Javeriana, Facultad de Ciencias Jurídicas. Grupo Editorial Ibáñez, p. 382.
} 
En este nuevo numeral de la CBJ de acuerdo con la propuesta se aclararían las diferencias entre la modalidad de cobertura por ocurrencia y por reclamación o Claims made, en donde se indica que esta última se refiere a la modalidad de cobertura del seguro de responsabilidad civil, que surge a partir de lo dispuesto en el artículo $4^{\circ}$ de la Ley 389. Permite que las partes consagren estipulaciones con el objeto de limitar en el tiempo la cobertura de una manera concreta, la cual dependerá de los plazos de vigencia para la presentación de reclamaciones ante la aseguradora.

Adicionalmente aclara que, en función de los riesgos cubiertos, se puede elegir cualquiera de las diferentes modalidades aplicables a esta cobertura, mencionadas en la jurisprudencia de la CSJ y del CE, a saber:

‘3 14.2.2.1. Reclamación pura: Aquella modalidad que cubre las reclamaciones que se produzcan durante la vigencia de la póliza, con independencia de la fecha en la cual haya ocurrido el hecho dañoso.

3.14.2.2.2. Reclamación con retroactividad: Aquella modalidad que cubre las reclamaciones que se produzcan durante la vigencia de la póliza, siempre y cuando los hechos hayan ocurrido durante la vigencia o durante el período de retroactividad pactado.

\subsection{Reclamación con período adicional para notificaciones: Aque-} lla modalidad que cubre las reclamaciones que se produzcan con posterioridad a la terminación de la póliza, siempre y cuando el hecho dañoso haya ocurrido con anterioridad a la expiración del seguro, bien sea dentro de su vigencia o dentro del período de retroactividad, si los hubiere.

\subsection{Reclamación con cobertura especial a futuro para hechos noti-} ficados: Aquella modalidad que cubre los hechos conocidos por el asegurado durante la vigencia, ocurridos durante la vigencia o durante el período de retroactividad pactado, que pudieran razonablemente dar lugar a una reclamación, siempre y cuando sean notificados a la aseguradora durante la vigencia de la póliza o durante el período adicional para notificaciones, si los hubiere.

Si en el futuro tales hechos dan origen a una reclamación, se considerará que tal reclamo ha sido presentado durante el correspondiente período de vigencia en el que dichos hechos fueron comunicados a la aseguradora.

3.14.2.3. Período de retroactividad: Intervalo de tiempo existente entre la fecha límite de retroactividad pactada, inclusive, y la fecha de inicio de vigencia de la póliza bajo la modalidad de cobertura por reclamación.

3.14.2.4. Hecho externo imputable al asegurado: Cualquier acontecimiento que produzca daños a terceros supuestamente perjudicados, cubiertos por el seguro, que dé lugar al surgimiento de un débito indemnizatorio a cargo del asegurado".

Sobra decir que estas estipulaciones resolverían en gran medida las recomendaciones realizadas por Nicolás Uribe antes mencionadas, para garantizar la correcta aplicación de esta modalidad de cobertura. 
Adicionalmente, esta propuesta incluye la necesidad de agregar dos cláusulas adicionales en todos los seguros pactados bajo esta modalidad, en caso de que apliquen. La primera se refiere a la posibilidad de que la aseguradora ofrezca convertir la modalidad de cobertura del seguro de Claims made a ocurrencia y evitar el vacío de cobertura que puede surgir al no tener una póliza vigente para reclamar sucesos ocurridos en el pasado y reclamados en la nueva vigencia, denominada cláusula de convertibilidad de la póliza, y la segunda con un carácter más general se refiere a que, en las renovaciones sucesivas con una misma compañía aseguradora, es obligatoria la concesión del período de retroactividad de cobertura de la póliza anterior, tal como lo refiere Uribe dentro de sus propuestas.

Con esta iniciativa de una compañía privada se evidencia la necesidad de dar claridad a las partes del contrato de seguros sobre esta modalidad de cobertura, pero además el interés de proteger al consumidor garantizando condiciones mínimas de cobertura. A la fecha de redacción de este documento no se conoce si la SFC aceptó o no esta propuesta.

Adicionalmente, tal como se mencionó en el capítulo anterior, es menester traer a colación la Circular 005 de 2020 emitida por el Contralor General de la Republica con el objeto exclusivo de informar a los funcionarios sobre la correcta vinculación de las compañías de seguros a los PRF.

En esta Circular el Contralor se detiene a explicar a los funcionarios de la CGR los asuntos relacionados con la vinculación de las compañías aseguradoras a los procesos de responsabilidad fiscal; empieza aclarando lo que la ley ya había indicado y es que la participación de las compañías aseguradoras en el PRF no es como responsables fiscales sino como garante de aquellos. Reconoce que las obligaciones de las aseguradoras están limitadas a lo negociado por las partes en el contrato de seguros incluyendo, pero no limitado a la vigencia asegurada, la suma asegurada, las coberturas y exclusiones, deducibles, disminución de la suma asegurada por siniestros previos y demás condiciones establecidas en los documentos que conforman la póliza.

La CGR debe, en el marco del PRF y en forma oportuna, solicitar a la entidad afectada, copia de los seguros que eventualmente pueden garantizar el cumplimiento de obligaciones, asegurar un bien, de responsabilidad civil para servidores públicos según sea el caso y que hayan estado vigentes desde la ocurrencia del hecho hasta el auto de apertura o el día en que se solicitan.

Teniendo en cuenta el hecho que da lugar al PRF, se deben analizar las pólizas de cara a su cobertura y analizar las condiciones particulares del contrato incluyendo la modalidad de cobertura, los períodos de prescripción, la retroactividad, exclusiones, entre otros.

Se concentra el Contralor en la modalidad de cobertura para aclarar que es necesario identificar cuáles son las modalidades de cobertura de la póliza, con el fin de determinar claramente cuál es la vigencia que debe afectarse en el curso del PRF, aclara además que si se trata de un seguro con modalidad ocurrencia la póliza que debe afectarse es la que se encontraba vigente al momento del acaecimiento del hecho que genera la pérdida, si se trata de una póliza con modalidad descubrimiento, se debe afectar la 
vigencia en la cual se tuvo conocimiento del hecho que da lugar a la pérdida y si se trata de una póliza modalidad Claims made, se debe afectar la póliza que esté vigente al momento de proferir el auto de apertura o vinculación de la aseguradora.

Esta aclaración sobre la modalidad de cobertura Claims made puede prestarse para inconvenientes de cara al análisis técnico de un siniestro, ya que si por ejemplo el asegurado informó como circunstancia que razonablemente dará lugar a la reclamación hechos relacionados con los del auto de apertura, la vigencia que debe afectarse es aquella en la que el asegurado tuvo conocimiento y lo informó así a la aseguradora y esta fecha puede ubicarse en una vigencia diferente a aquella en donde la CGR emite el auto de apertura del proceso.

Se encuentra como positivo que el Contralor indica a los operadores fiscales que no deben realizar indebidas acumulaciones de vigencias y por lo mismo la vinculación de la aseguradora se debe hacer respetando la modalidad de cobertura negociada en el contrato de seguros correspondiente. Y que la circular termina con el reconocimiento expreso de la legalidad de la ley 389, el Código de Comercio y las condiciones de las pólizas y la necesidad de armonizar estas estipulaciones con aquellas que rigen el PRF.

Aunque esta es una iniciativa interesante, llama la atención el medio elegido para su difusión teniendo en cuenta los efectos que tienen las circulares sobre los administrados. Tal como lo mencionó el CE (17/05/2012, M.P. Víctor Hernando Alvarado, Exp. 11001032500020080011600 (2556-08)) las circulares administrativas se limitan a reproducir el contenido de otras normas, las decisiones de otras instancias o brindar orientaciones e instrucciones a sus destinatarios sin que contengan decisiones, es decir, esta circular es orientadora de la gestión de las contralorías, pero de cierto modo, no es de obligatoria aplicación, por lo que no se resuelve de raíz el problema de inseguridad jurídica planteado por esta misma entidad.

Finalmente, es relevante mencionar que en estos momentos se discute en el Congreso de la República una iniciativa de unificación de los Códigos Civil y Comercial presentada por la Universidad Nacional de Colombia dentro de la cual se trata de alguna forma este tema. La propuesta de nuevo Código incluye el siguiente artículo:

Artículo 1505: En el seguro de responsabilidad la configuración del siniestro se determinará de acuerdo con la modalidad de cobertura pactada:

1. En la modalidad de ocurrencia se entenderá configurado en el momento en que acaezca el hecho externo imputable al asegurado, fecha a partir de la cual correrá la prescripción respecto de la víctima. Frente al asegurado ello ocurrirá desde cuando la víctima le formula la petición judicial o extrajudicial;

2. En la modalidad de reclamación se entenderá configurado cuando el damnificado formule el reclamo al asegurado o al asegurador durante la vigencia respectiva del seguro, así se trate de hechos ocurridos con anterioridad a su iniciación;

3. En la modalidad de ocurrencia con período de reclamaciones se definen como cubiertos los hechos que acaezcan durante la vigencia del seguro de responsabilidad, siempre que la reclamación del damnificado al asegurado o al asegurador se efectúe dentro del término estipulado en el contrato, el cual no será inferior dos años. 
Como se ve, este artículo regula la configuración del siniestro en cada una de las modalidades aplicables para el seguro de responsabilidad civil, incluyendo la modalidad de cobertura por reclamación o Claims made. Con esta consagración de alguna forma se soluciona la sugerencia que hace Uribe a determinar con claridad la ocurrencia del siniestro en los seguros con esta modalidad.

Finalmente, la Unidad de Regulación Financiera presentó un Proyecto de Decreto “por el cual se modifica el Decreto 2555 de 2010 en lo relacionado a las normas aplicables a algunas operaciones de las entidades aseguradoras y se dictan otras disposiciones" relacionado exclusivamente con la modalidad de cobertura Claims made. En este proyecto de Decreto, aparentemente se pretende llenar el vacío normativo existente frente a las condiciones especiales de esta modalidad, teniendo en cuenta la relevancia que ha adquirido este tema y las situaciones adversas que se han generado, tal como lo mencionó la defensa en el PRF del IDU, contado en capítulos previos.

En este se tratan varios temas, entre los cuales se encuentra la definición de circunstancia, la unidad de evento en siniestros de seguros con esta modalidad, la definición misma del siniestro, entre otros asuntos; sin embargo, es necesario generar correcciones y ampliaciones, por ejemplo, que la aplicación del mismo no sea solo para seguros de responsabilidad de directores y administradores, sino a todos los seguros de responsabilidad civil que puedan llegar a tener esta modalidad de cobertura. $\mathrm{O}$ explicar claramente si el pacto de fecha de retroactividad es obligatorio o se aplicará lo indicado en el decreto en caso de que se pacte este, finalmente y sólo con el fin de ilustrar, un tema dejado de lado en este proyecto que debería ser regulado es el del período adicional de notificaciones.

Este tema, como se ha visto, es bastante especializado y es por esto que el proyecto tendrá que ser profundizado, comentado con todas las áreas que se verán impactadas por este, para finalmente entregar la mejor regulación posible.

Luego de analizar estos seis actores con sus propuestas ante las críticas y los inconvenientes que ha generado esta modalidad de cobertura, encontramos en un primer momento una evidente intención de solucionar los inconvenientes que se han presentado con la aplicación de esta modalidad de cobertura, situación positiva pues garantiza su continuidad y de esta forma conservar la actualidad de las normas de seguros en Colombia con respecto al mercado de seguros y reaseguros del exterior.

Es posible concluir entonces, que estos inconvenientes se han presentado en mayor medida por la falta de regulación clara sobre esta modalidad, ya que este silencio tiene un impacto importante en la relación con los consumidores financieros y sólo se encuentra regulación en un artículo de la ley 398 de 1997; se requerirá entonces mayor participación de la legislación en este tema para cerrar vacíos y evitar que la balanza esté desequilibrada en los términos de la relación jurídica. Sin embargo, se resalta que en la iniciativa que hay actualmente en el congreso de unificación de los códigos se consagra un artículo en este sentido, pero es insuficiente de cara las controversias que genera esta modalidad. 


\section{CONCLUSIONES}

La modalidad de cobertura por reclamación o Claims made fue traída a Colombia a través de la Ley 389 de 1997 para modernizar la institución del seguro en el país. Esto, a su vez, tuvo fundamento en los problemas que se presentaban con la modalidad de cobertura por ocurrencia, consistentes en que no existía una respuesta eficiente a los inconvenientes que suponía asegurar riesgos de cola larga por daños tardíos y en los cuales, las compañías aseguradoras debían mantener sus reservas por largos períodos de tiempo.

En esta modalidad cambia el significado de siniestro en los seguros de responsabilidad civil, pues tradicionalmente se ha entendido como la ocurrencia del hecho dañoso, pero para Claims made el siniestro lo configura la reclamación que efectúe el tercero afectado al asegurado o directamente a la aseguradora, si decide ejercer la acción directa.

Esta modalidad es una limitación temporal del siniestro, la cual tiene beneficios, pero evidentemente supone unos límites a la cobertura. De acuerdo con sus características, permite distintas alternativas, unas más restrictivas que otras. La modalidad Claims made regulada en Colombia no es la más gravosa pues no exige que se presente la reclamación y que, además, esta sea reportada a la aseguradora durante la vigencia del seguro.

Además, permite pactar dos períodos especiales, como complemento. Uno es el período de retroactividad, el cual puede entenderse como una cobertura de riesgo putativo, teniendo en cuenta que permite asegurar hechos ocurridos con anterioridad a la vigencia, pero que sean reclamados en esta. El otro período consiste en unas coberturas prospectivas, en la que el asegurado podrá dar aviso de circunstancias durante la vigencia y, sin importar el momento en el que se constituya el siniestro, este tendrá cobertura. También podrá contratar el período adicional de notificaciones, en el cual tendrá la posibilidad de informar circunstancias o reclamaciones presentadas por hechos ocurridos en la vigencia, pero reclamados con posterioridad a esta.

Se han encontrado menciones de algunos doctrinantes en el sentido de indicar que estas cláusulas son abusivas, que son un atentado en contra de la buena fe de los asegurados, que generan un desequilibrio contractual, muestran una asimetría de las prestaciones e implican un abuso de la posición dominante por parte de las aseguradoras o que se trata de una modalidad excesivamente restrictiva. En cualquier caso, es necesario hacer hincapié en la legalidad de estas y resaltar que, aunque limitan temporalmente la cobertura, esto no las hace abusivas, especialmente si se recuerda que su pacto es voluntario y que tiene mecanismos adicionales que se pueden estipular para proteger al asegurado y a la víctima, como los períodos de retroactividad, el aviso de circunstancias, el período extendido de reportes. En definitiva, es una modalidad que aunque puede tener desventajas, también tiene ventajas para ambas partes del contrato de seguro.

El artículo 1056 del Código de Comercio establece la libertad negocial de las aseguradoras para elegir los riesgos que desean asumir y en este sentido, no es posible afirmar que la modalidad por reclamación deba proveer cobertura absoluta. 
En los pronunciamientos expuestos de la CSJ se puede concluir que este órgano reconoce la legalidad de la modalidad reclamación y, por ende, la aplica de forma natural en los contratos de seguro de responsabilidad civil. Además, sus interpretaciones se encuentran en línea con lo estudiado y establecido por la doctrina, aunque no ha desarrollado completamente el alcance de la modalidad Claims made como sí lo ha hecho la doctrina nacional, y entonces, no ha profundizado, por ejemplo, en los períodos adicionales de notificación, ni en las cláusulas de aviso de circunstancias, y tampoco ha diferenciado, a profundidad, la modalidad Claims made de la modalidad Sunset.

En los salvamentos de voto de los magistrados Salazar y Tolosa no se contemplan la totalidad de las características de la modalidad, no tiene en cuenta el origen de esta y olvidan aspectos jurídicos básicos del derecho de seguros como la prescripción, los elementos del contrato de seguros y la protección al consumidor. Y más importante aún, no se replicaron en el tiempo estas posturas.

Por su parte, la SFC ha entendido que la Ley 389 de 1997 abrió un abanico de posibilidades a las partes del contrato de seguro autorizando la suscripción de pólizas bajo la modalidad de cobertura por reclamación y ha confirmado que ésta es perfectamente aplicable y que no es una cláusula abusiva por el mero hecho de pactarla.

Del análisis de los fallos estudiados de la CGR, se encontró que, con el fin de proteger el patrimonio público, las decisiones que ha tomado son abiertamente contrarias a las normas vigentes colombianas y a las posiciones que han asumido las Altas Cortes e incluso la Superintendencia Financiera de Colombia. Esta situación violenta el ordenamiento, genera inseguridad jurídica respecto a las coberturas de los seguros y por lo mismo, modifica la oferta que el mercado de seguros y reaseguros está dispuesto a entregar teniendo en cuenta estos fallos, "se ha generado una entendible preocupación en el sector asegurador y, por supuesto, en los reaseguradores internacionales para quienes la responsabilidad fiscal determinada por la Contraloría General de la República es una figura atípica en el concierto internacional, (...) a lo que se agrega la emisión de algunos fallos que han alarmado al mercado por adoptar interpretaciones ajenas al rigor de la disciplina del derecho y de la técnica de seguros" ${ }^{937}$.

Teniendo en cuenta que los seguros apalancan el desarrollo económico de los países, el impacto de estas decisiones no sólo afecta al sector asegurador, sino que además desincentiva la inversión extranjera y finalmente desacelera la economía colombiana.

Por ello, entendiendo el impacto negativo que sus decisiones habían tenido, la CGR emitió la Circular 005 del 2020 buscando corregir, de alguna forma, la percepción que el mercado de seguros y reaseguro tuvo para dejar de otorgar estas coberturas en Colombia. Sin embargo, el mecanismo seleccionado para lograrlo no tiene suficiente fuerza, no aplica para todos los actores, es solo una recomendación del Contralor General de la República, por lo que, si bien es un avance y hay al menos una evidencia

\footnotetext{
37 Díaz- Granados, Juan Manuel. (2015). La Responsabilidad Fiscal y su incidencia en los seguros. Derecho de seguros y reaseguros, Liber Amicorum en homenaje al profesor Arturo Diaz Bravo. Colección de estudios, Pontificia Universidad Javeriana, p. 124.
} 
de su efectividad, será necesario esperar el desarrollo de los demás procesos de responsabilidad fiscal que se encuentran en curso.

Derivado del análisis de las propuestas estudiadas y del contexto analizado, es posible concluir entonces que los inconvenientes de la modalidad de cobertura por reclamación o Claims made se han presentado en mayor medida por la falta de regulación clara sobre esta, ya que este silencio tiene un impacto importante en la relación con los consumidores financieros y sólo se encuentra regulación en un artículo de la ley 398 de 1997. Así lo manifestó el doctor Gabriel Vivas (2020), en sus comentarios al Proyecto de Ley presentado para regular la modalidad:

"Teniendo en cuenta que la trasferencia eficiente de riesgos a la entidades aseguradoras requiere de claridad al momento de establecer las condiciones y los parámetros que permiten brindar cobertura de los riesgos que se desean transferir, el marco normativo debe propender por brindar unas reglar claras y precisas que permitan la suscripción de este tipo de pólizas, de tal manera que tanto las aseguradoras como lo asegurados, puedan definir los alcances y condiciones en que se desarrolla la operación del seguro".

Teniendo en cuenta el contexto analizado, se encuentra que existe una evidente intención de solucionar los inconvenientes que se han evidenciado con la aplicación de esta modalidad de cobertura, situación positiva pues garantiza su continuidad y de esta forma se conserva la vigencia de las normas de seguros en Colombia con respecto al mercado de seguros y reaseguros del exterior. Tanto es así, que varias de las propuestas analizadas son proyectos de ley que pretenden cerrar las brechas y vacíos de esta modalidad. Se requerirá entonces mayor participación de la regulación en este tema para cerrar vacíos y evitar que la balanza esté desequilibrada en los términos de la relación jurídica.

\section{BIBLIOGRAFÍA}

C-388 de 2008. Corte Constitucional. 23 de abril de 2008. M.P.: Clara Inés Vargas Hernández.

C-648 de 2002. Corte Constitucional. 12 de agosto de 2002. M.P.: Jaime Córdoba Triviño.

Circular 005 de 2020. Contralor General de la República. 16 de marzo de 2020.

Consejo de Estado. Jorge Octavio Rozo contra el Ministerio de Hacienda y Crédito Público y el Ministerio de la Protección Social. Magistrado ponente: Víctor Hernando Alvarado, Exp. 11001-03-25-000-2008-00116-00(2556-08). (17 de mayo de 2012)

Consejo de Estado. La Previsora Compañía de Seguros en contra del Tribunal Administrativo de Cundinamarca, Magistrado ponente: Gustavo Eduardo Gómez. Exp. 11001-03-15000-2014-00624-00 (29 de mayo de 2014).

Consejo de Estado. La Previsora S.A en contra de la Contraloría Departamental del Atlantico, Magistrado ponente: Alberto Yepes Barreiro. Exp. 08001-23-31-000-2010-00612-01 (22 de febrero de 2018).

Consejo de Estado. La Previsora Compañía de Seguros en contra del Tribunal Administrativo de Caquetá, Magistrado ponente: Sandra Lisseth Ibarra, Exp. 11001-03-15-0002018-00027-00(AC). (12 de marzo de 2018). 
Consejo de Estado. La Previsora Compañía de Seguros en contra del Tribunal Administrativo de Casanare, Magistrado ponente: Rocío Araújo Oñate, Exp. 11001-03-15-000-201702479-00(AC) (16 de agosto de 2018).

Consejo de Estado. La Previsora S.A. contra el Tribunal Administrativo del Cauca, Magistrado ponente: Stella Jeannette Carvajal, Exp.11001-03-15-000-2018-02290-00 (28 de noviembre de 2018).

Consejo de Estado. La Previsora Compañía de Seguros en contra del Tribunal Administrativo de Caquetá, Magistrado ponente: Jorge Octavio Ramírez, Exp. 11001-03-15-0002018-00027-01(AC) (12 de febrero de 2019).

Constitución Política de Colombia. (20 de Julio de 1991).

Contraloría General de la República. Licorera del Valle, PRF 6-007/11 (20 de marzo de 2012).

Contraloría General de la República. Unidad Administrativa Especial de Servicio Públicos UAESP, PRF-2014-02038_UCC-PRF 038/2012 (09 de octubre de 2017).

Contraloría General de la Republica. (17 de agosto de 2020). Obtenido de https://www. contraloria.gov.co: https://www.contraloria.gov.co/contraloria/la-entidad

Contraloría General de la República. Instituto de Desarrollo Urbano de Bogotá, PRF 201405388. (12 de junio de 2019).

Contraloría General de la República. Industria Licorera de Caldas, PRF-2015-00329 (29 de agosto de 2019).

Contraloría General de la República. Auto de apertura No. 945. PRF 014-2019. (8 de noviembre de 2019)

Corte Suprema de Justicia. Sala de Casación Civil. Magistrado ponente: Jaime Alberto Arrubla Paucar, 10 de febrero de 2005, Exp. 7614.

Corte Suprema de Justicia. Magistrado ponente: Jaime Arrubla Paucar. SC. 15 de diciembre de 2006. Radicado número: 52001-31-03-004-2000-00276-01.

Corte Suprema de Justicia. Magistrado ponente: Ruth Marina Díaz. SC. 30 de octubre de 2007. Radicado número: 0500131030082002-00565-01.

Corte Suprema de Justicia. Magistrado ponente: Jaime Alberto Arrubla Paucar. SC. 09 de agosto de 2010. Radicado número: 1100131030432004-00524-01.

Corte Suprema de Justicia. Magistrado ponente: Ruth Marina Díaz. SC. 30 de agosto de 2010. Radicado número: 11001-3103-041-2001-01023-01.

Corte Suprema de Justicia. Magistrado ponente: Fernando Giraldo Gutiérrez. SC. 18 de noviembre de 2013. Radicado número: 1100131030412000-01098-01.

Corte Suprema de Justicia. Magistrado ponente: Ruth Marina Díaz. SC10048-2014. 31 de julio de 2014. Radicado número: 11001-3103-015-2008-00102-01.

Corte Suprema de Justicia. Magistrado ponente: Aroldo Wilson Quiroz. SC10300-2017. 18 de julio de 2017. Radicación número: 76001-31-03-001-2001-00192-01. 
Corte Suprema de Justicia. Magistrado ponente: Aroldo Wilson Quiroz. SC130-2018. 12 de febrero de 2018. Radicado número: 110001-31-03-031-2002-01133-01.

Corte Suprema de Justicia. Magistrado ponente: Luis Alonso Rico Puerta. SC5217-2019. 03 de diciembre de 2019. Radicado número: 11001-31-03-015-2008-00102-01.

Decreto 403 de 2020. Presidencia de la República (16 de marzo de 2020).

Díaz-Granados, J. M. (2012). El seguro de responsabilidad civil. Bogotá: Editorial Universidad del Rosario y Pontificia Universidad Javeriana, Facultad de Ciencias Jurídicas.

Díaz Granados Ortiz, Juan Manuel. La Responsabilidad Fiscal y su incidencia en los seguros. Derecho de Seguros y Reaseguros, Liber Amicorum en homenaje al profesor Arturo Díaz Bravo. Colección estudios, Pontificia Universidad Javeriana, Grupo Editorial Ibáñez, CEDEP, CILA, Marzo 2015.

Exposición de motivos de la Ley 389 de 1997. Gaceta del Congreso Senado y Cámara. Santafé de Bogotá, D.C., 20 de diciembre de 1995.

Fernandez Muñoz, M. L. (2002). "Las Clausulas Claims made en el seguro de responsabilidad civil”. Revista Estudios Socio Jurídicos, 213 - 245.

Galindo Vacha, Juan Carlos. (2015). Temas Relevantes de la Responsabilidad Fiscal y del Derecho de Seguros. Derecho de Seguros y Reaseguros, Liber Amicorum en homenaje al profesor Arturo Díaz Bravo. Derecho de Seguros y Reaseguros, Liber Amicorum en homenaje al profesor Arturo Díaz Bravo. Colección estudios, Pontificia Universidad Javeriana, Grupo Editorial Ibáñez, CEDEP, CILA, Marzo 2015.

Garrigues, J. (1983). Contrato de seguro terrestre. Madrid: Imprenta Aguirre.

Jaramillo Jaramillo, C. I. (2011). Derecho de seguros. Bogotá: Editorial Temis y Pontificia Universidad Javeriana.

JARAMILLO, C. I. (2011). "Delimitación temporal de la cobertura en el Seguro de la Responsabilidad Civil - Adopción del sistema de aseguramiento comúnmente conocido como "Claims made"” -. Revista Ibero-latinoamericana de Seguros, 145-214.

Laudo arbitral Proyectar Valores S.A. Comisionista de Bolsa en Liquidación forzosa administrativa contra Chubb de Colombia Compañía de Seguros S.A. y Chartis Seguros Colombia S.A., 2977. Tribunal de arbitramento en el Centro de Arbitraje y Conciliación de la Cámara de Comercio de Bogotá (4 de noviembre de 2014).

Laudo arbitral Fondo Nacional del Ahorro Carlos Lleras Restrepo en contra de Mapfre Seguros Generales De Colombia S.A. Tribunal de arbitramento. (10 de julio de 2020).

Ley 389 de 1997. Congreso de la República (18 de julio de 1997).

Ley 610 de 2000. Congreso de la República (18 de agosto de 2000).

Ordoñez, A. (1998). El contrato de seguro. La Ley 389 de 1997 y otros estudios. Bogotá : Universidad Externado de Colombia.

Pavelek Zamora, E. (s.f.). "Delimitación temporal en el seguro de responsabilidad civil la nulidad del "Claims made" ¿otra vuelta a la tuerca?" Gerencia de riesgos, num. 41, Fundación Mapfre Estudios. 
Seguros Generales Suramericana S.A. (Febrero de 2020). Propuesta de Circular Externa de la Superintendencia Financiera de Colombia sobre cláusulas Claims made. Medellín, Antioquia, Colombia.

Superintendencia Financiera de Colombia. (24 de mayo de 2002). Doctrinas y conceptos Financieros 2002, el seguro de responsabilidad civil, Concepto 2002001008-2: Superintendencia Financiera de Colombia. Obtenido de Supeintendencia Financiera de Colombia sitio web : https://www.superfinanciera.gov.co/jsp/Publicaciones/ publicaciones/loadContenidoPublicacion/id/18804/dPrint/1/c/0

Superintendencia Financiera de Colombia. (29 de noviembre de 2016). Conceptos 2016, seguro de responsabilidad civil extracontractual: Superintendencia Financiera de Colombia. Obtenido de Superintendencia Financiera de Colombia: https://www. superfinanciera.gov.co/inicio/normativa/conceptos-y-jurisprudencia-/conceptos/ conceptos--10085964

Superintendencia Financiera de Colombia. (27 de abril de 2018 ). Consulta Especifica, Dirección Legal de Seguros, Respuesta Final: Superintendencia Financiera de Colombia.

Superintendencia Financiera de Colombia. (20 de abril de 2020). Acerca de la SFC: Superintendencia Financiera de Colombia. Obtenido de Superintendencia Financiera de Colombia sitio web: https://www.superfinanciera.gov.co/jsp/Publicaciones/ publicaciones/loadContenidoPublicacion/id/60607/f/0/c/0\#naturaleza1

Uribe LozAda, N. (2013). El régimen general de responsabilidad de los administradores de sociedades y su aseguramiento. Bogotá: Pontificia Universidad Javeriana, Facultad de Ciencias Jurídica. Grupo Editorial Ibáñez.

Uribe Lozada, N. (2016). Análisis técnico - jurídico de la modalidad de cobertura por reclamación o "Claims made" en los seguros de responsabilidad civil a la luz del ordenamiento jurídico colombiano. Revista Ibero-Latinoamericana de Seguros, 13-89.

Unidad de Regulación Financiera. Proyecto de Decreto "por el cual se modifica el Decreto 2555 de 2010 en lo relacionado a las normas aplicables a algunas operaciones de las entidades aseguradoras y se dictan otras disposiciones". Bogotá. (18 de septiembre de 2020)

VÁSQUeZ Vega, D. (2020). "Los seguros de responsabilidad civil en el derecho colombiano". En: A. GAVIRIA, Estudios de responsabilidad civil (pp. 495-555). Medellín : Editorial EAFIT.

VIVAS, G. J. (21 de septiembre de 2020). Observaciones al proyecto de Decreto "por el cual se modifica el Decreto 2555 de 2010 en lo relacionado a las normas aplicables a algunas operaciones de las entidades aseguradoras y se dictan otras disposiciones" en relación con la limitación temporal . Bogotá. 